\title{
SYNTHESIS AND CHARACTERIZATION OF AMPHIPHILIC ARENEPHOSPHONATES AS WATER-SOLUBLE MICELLULAR RADIOLUMINESCENT PROBES
}

DAVID N. FRENCH, JAY G. SIMMONS, HENRY O. EVERITT, STEPHEN H. FOULGER, GARY M. GRAY

\begin{abstract}
This work describes the synthesis and characterization of a series of arenephosphonic acid salts for use as water soluble down-converters in optogenetic assays. Two phosphonate salts based on anthracene and naphthalene were synthesized through cleavage of phosphonate esters. A third amphiphilic salt, developed from a long-alkylchain modified naphthalene, was produced in the same manner to demonstrate micelle formation. Two techniques were used to determine if any of the salts showed micelle behavior: 31P NMR and fluorescence spectroscopy. Interestingly, all three compounds exhibited micelle formation in water. UV-induced fluorescence of NapPONa and AntPONa revealed a secondary emission profile with maximum excitation wavelengths that lie on top of the primary emission profile. This secondary emission can be attributed to the emission of the micellular structure based on solidstate fluorescence experiments. Moderate $x$-ray induced radioluminescence was observed in the solid forms of each compound. A solution of amphiphilic NapPONa demonstrated both concentrationdependent and micelle-dependent radioluminescence, indicating the positioning of aromatic rings in a micelle is inducive to a radioluminescent response. Furthermore, the emission wavelength of this compounds lies on top of the excitation wavelength of channelrhodopsin-2, a well-studied optogenetic target.
\end{abstract}

\section{Introduction}

Our group is currently investigating the design and use of new tools and materials for optogenetics. We have focused on a main component of optogenetics: the delivery of light of a certain wavelength to a specific target. These targets are specially engineered neurons containing light-sensitive proteins that generate a recordable synaptic response upon absorption of a certain wavelength. ${ }^{1-4}$ We have focused on non-invasive solutions to current light delivery systems that cause unwanted physiological effects due to physical tissue damage and local heating. ${ }^{5-8}$

A combination of a tissue-penetrative light source in conjunction with a local converter could provide the necessary wavelengths to precisely activate neurons without unacceptable loss to surrounding tissue. Although bodily tissue readily absorbs most regions of visible light, there are two biological

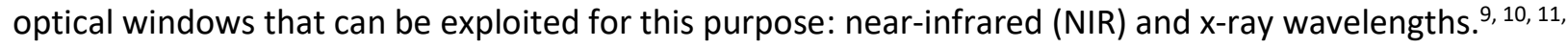
12, 13 Despite the limited penetration depth of NIR, its use in combination with local lanthanide-doped silica nanoparticle up-converters has proven to be an effective non-invasive optogenetic tool. ${ }^{14}$ Short wavelength light carries more energy, penetrates deeper in the case of $x$-rays, and may prove to be a better primary light source. ${ }^{15}$ Our group has already demonstrated that the conversion of UV to blue light, using a class of organic aromatic materials known as scintillators, can induce a synaptic response in an in vitro optogenetic assay. ${ }^{16}$ While the polymeric materials described therein were determined to be non-toxic, they only exhibited weak scintillation under exposure to x-rays (i.e. radioluminescence) and were not water soluble. To be most effective as a non-invasive optogenetic tool, the materials must be both water soluble and highly radioluminescent. 
Recent research into water-soluble scintillators indicates linear alkyl benzene sulfonates (LAS) exhibit observable emission under irradiation with $\psi$-rays from $\mathrm{Cs}^{137} \cdot{ }^{17}$ However, it is unknown if $\mathrm{x}$-rays elicit the same response, the emission spectrum is outside the absorbance of all biologically relevant optogenetic targets, and there is limited information on the mechanism of action of these scintillators. Linear alkyl sulfonates are commercially used as detergents and soaps, and form micelles in water.$^{18}$ Micelle formation has a significant effect on UV-excited fluorescence. ${ }^{19,20}$ It is possible that micelle formation induces aryl ring alignment in LAS, thereby increasing the overall absorption of the radiation. This is consistent with the observation that solid crystalline organic aromatics and inorganic nanoparticles generally have higher emission intensities than solution-state scintillators. ${ }^{21,22}$ The micellular structure of an amphiphilic organic aromatic compound could mimic that of the crystalline compounds and produce a bright water-compatible scintillator. The design of an amphiphilic organic aromatic scintillator with an appropriate emission spectrum could be a very useful tool for non-invasive optogenetics.

Our group has previously demonstrated that phosphonate ester functionalization of anthracene increases the solution-state UV-induced quantum efficiency and increases the radioluminescent light yield. ${ }^{23,}{ }^{24}$ Cleavage of phosphonate esters can produce phosphonic acids and salts that are water soluble, non-toxic and possibly amphiphilic. This present work describes the syntheses of 2-anthryl- and 2-naphthylphosphonate salts (Schemes 1 and 2) and an 2- (alkylnaphthylphosphonate salt) similar to the LAS (Scheme 1). The optical properties, including radioluminescence, are characterized. Interestingly, all of the arrylphosphonates exhibited micelle formation in water, and one demonstrated concentrationand micelle-dependent radioluminescence.

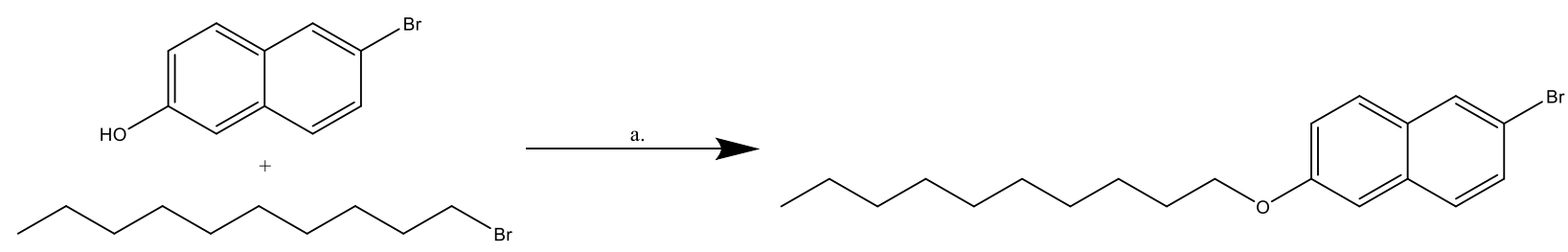

Scheme 1. Synthesis of Aliphatic Precourser, DecNapBr. [a] Acetone, $\mathrm{K}_{2} \mathrm{CO}_{3}$ 

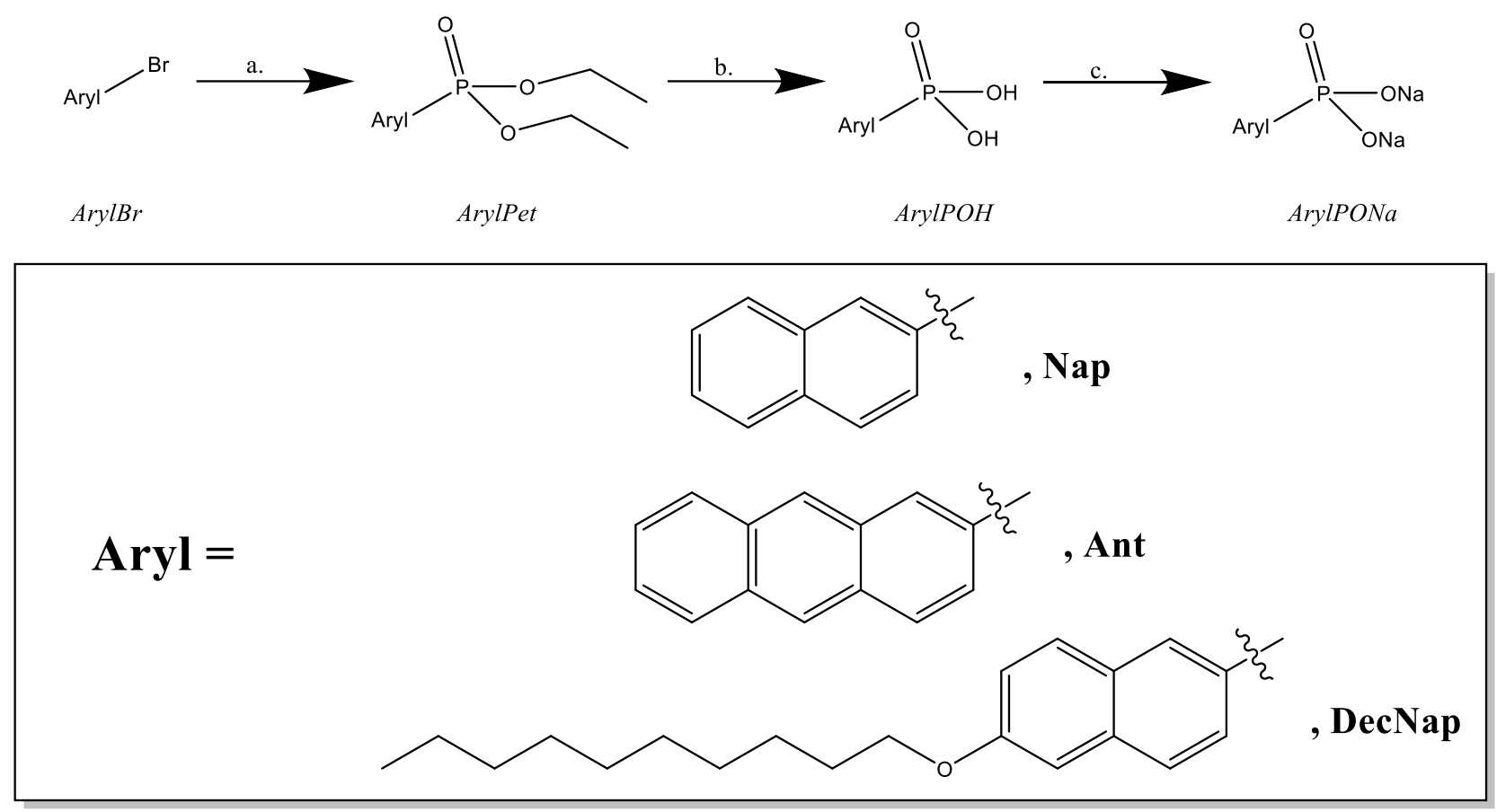

Scheme 2. General Synthesis of Arene Phosphonate Salts. [a] ArylPet. triethylphosphite, mesitylene, $\mathrm{NiBr}$, reflux 20 hr. [b] ArylPOH. 1. bromotrimethylsilane, dichloromethane, $6 \mathrm{hr}$. 2. Methanol, $1 \mathrm{hr}$. [c] AryIPONa. Sodium hydroxide, water, until dissolved.

\section{Results}

\section{Synthesis}

The aromatic phosphonate salts were synthesized in a three-step process beginning with the bromoarenes. Most of the bromo-arenes were commercially obtained; however, the precursor amphiphilic naphthalene compound $\mathrm{DecNapBr}$ was synthesized through a Williamson ether synthesis from 1-bromodecane and 2-bromo-6-naphthol using $\mathrm{K}_{2} \mathrm{CO}_{3}$ as a base. The addition of the phosphonate ester was accomplished using a modified Arbuzov reaction between the bromoarene and triethylphosphite with $\mathrm{NiBr}_{2}$ as a catalyst resulting in pure products in moderate yield. ${ }^{25}$ Cleavage of the phosphonate ester, was done first by addition of TMS to the ester with Br-TMS, followed by cleavage with methanol to afford the arylphosphonic acid in quantitative yield. The final phosphonate salts were synthesized by stoichiometric addition of sodium hydroxide to aqueous solutions of the arylphosphonic acids. Column chromatography proved successful in purifying the esters, while simple washings with methanol were sufficient for purification of the phosphonic acids and salts. The solubilities of the phosphonic acids were low to negligible in organic media, with the exception of DMSO. The salts of NapPONa and AntPONa were fully soluble in water. The maximum concentration of DecNapPONa that resulted in a clear aqueous solution was $150 \mathrm{mM}$.

\section{NMR Characterization}


The arylphosphonate esters and acids were fully characterized by ${ }^{1} \mathrm{H},{ }^{13} \mathrm{C}\left\{{ }^{1} \mathrm{H}\right\}$, and ${ }^{31} \mathrm{P}\left\{{ }^{1} \mathrm{H}\right\} \mathrm{NMR}$ spectroscopy. Two dimensional NMR experiments $\left({ }^{1} \mathrm{H}-{ }^{13} \mathrm{C} \mathrm{HSQC},{ }^{1} \mathrm{H}-{ }^{1} \mathrm{H}\right.$ COSY, and $\left.{ }^{1} \mathrm{H}-{ }^{13} \mathrm{C} \mathrm{HMBC}\right)$ were used to assign ${ }^{1} \mathrm{H}$ and ${ }^{13} \mathrm{C}$ resonances. The TMS substituted arylphosphonates and salts were characterized only by ${ }^{31} \mathrm{P}\left\{{ }^{1} \mathrm{H}\right\}$ NMR spectroscopy. Full assignments were given to the AntPxx, NapPxx, and DecNapPxx series. Select chemical shifts and coupling constants of the esters, acids, and salts are recorded in Tables 1 and 3.

The chemical shifts of phosphorus nuclei are extremely sensitive to the surrounding chemical environment. Therefore, it makes an excellent probe into the properties of both the micellular species and their precursors. The transition from et to TMS shifts the signal from approximately $20 \mathrm{ppm}$ upfield close to $0 \mathrm{ppm}$. The transition from TMS to $\mathbf{O H}$ shifts it back downfield to approximately $14 \mathrm{ppm}$. The ${ }^{31} \mathrm{P}$ chemical shifts are relatively insensitive to the nature of the aryl group but are found in the order DecNapPxx > AntPxx > NapPxx regardless of the nature of the other phosphorus substituents. However, the signal of the ipso-carbon and the $\mathrm{C}-\mathrm{P}$ coupling constant do not follow the same trend. NMR studies pertaining to the critical micelle concentration $(\mathrm{CMC})$ are described below.

Table 1. Relevant chemical shifts of phosphorus and carbon atom

\begin{tabular}{|l|c|c|c|}
\hline Compound & $\begin{array}{c}{ }^{31} \mathrm{P} \text { Chemical Shift } \\
(\mathrm{ppm})\end{array}$ & $\begin{array}{c}{ }^{13} \mathrm{C} \text { Chemical Shift of P-C } \\
(\mathrm{ppm})\end{array}$ & $\begin{array}{c}\left|{ }^{1} \mathrm{~J}_{\mathrm{CP}}\right| \\
(\mathrm{Hz})\end{array}$ \\
\hline AntPet $^{\mathrm{a}}$ & 20.37 & 125.07 & 188.0 \\
\hline NapPet & 20.34 & 125.44 & 186.9 \\
\hline DecNapPet & 21.65 & 122.58 & 190.7 \\
\hline AntPTMS & 1.33 & - & - \\
\hline NapPTMS & 1.57 & - & - \\
\hline DecNapPTMS & 2.06 & - & 180.6 \\
\hline AntPOH & 13.81 & 130.98 & 174.2 \\
\hline NapPOH & 13.96 & 131.45 & 183.1 \\
\hline DecNapPOH & 14.60 & 128.64 & - \\
\hline
\end{tabular}

a. From Reference 24

\section{Optical Characterization}

\section{Absorbance/Fluorescence}

The absorbance profiles of the compounds were taken to determine the optimal fluorescence excitation wavelengths. The normalized profiles are displayed in Figure 1 and relevant data are reported in Table 2 . The absorbance and emission spectra of the salts presented in Figures R3-1 and R3-2 are for solutions of monomers below the CMC. The absorbances of all compounds are dominated by the $\pi-\pi *$ transitions of the aromatic systems and are slightly redshifted from those of the unsubstituted arenes. The conversion to a phosphonate ester into a phosphonic acid causes a slight blue shift in all cases except for NapPet $\rightarrow$ NapPOH. In all cases a blue shift is observed when the phosphonic acid is converted into a phosphonate salt, however the absorbances vary less than $10 \mathrm{~nm}$ for all compounds containing the same aryl group

(Nap, Ant, or DecNap). 

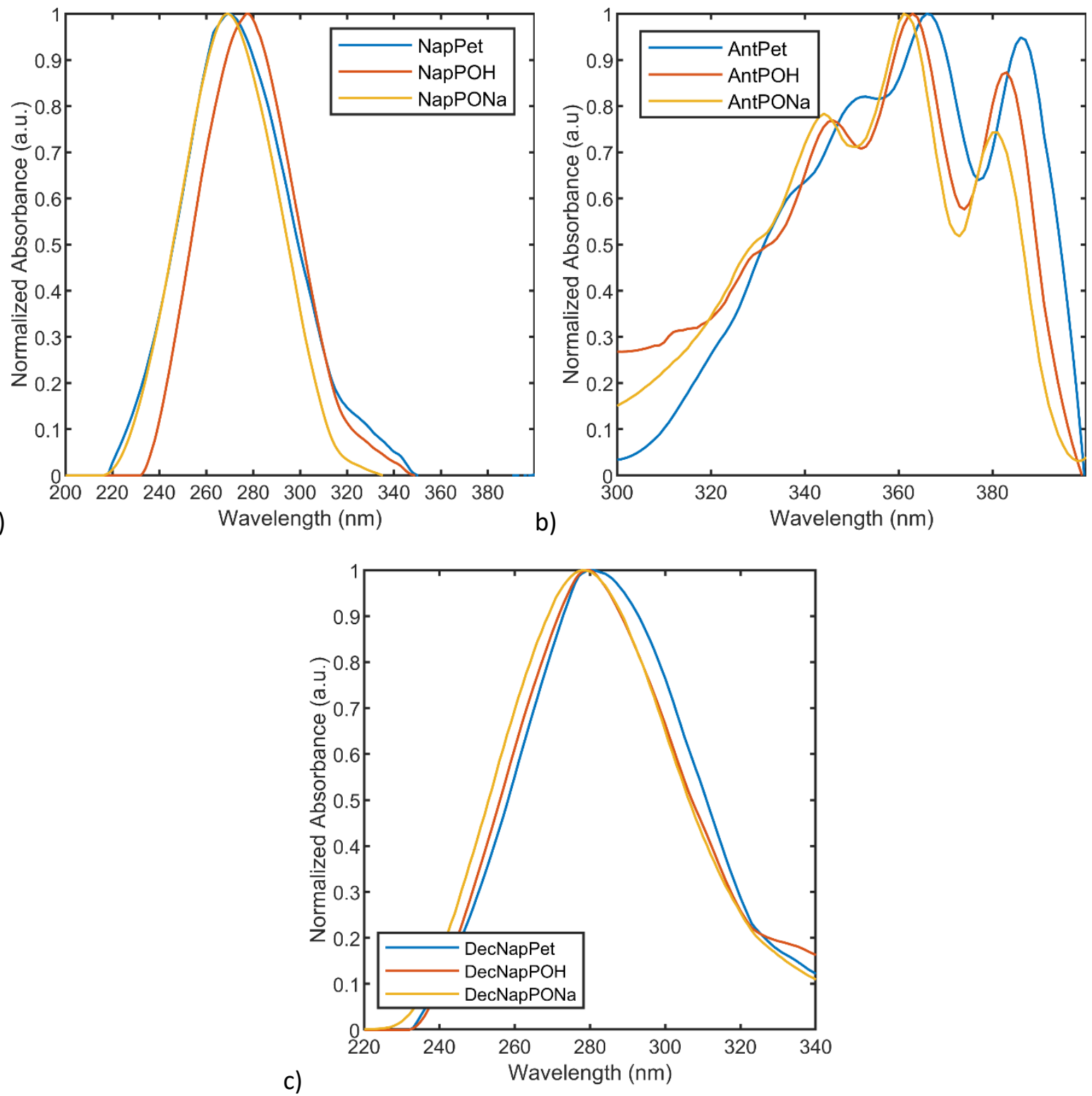

Figure 1. Absorbance of a) NapPxx, b) AntPxx, c) DecNapPxx

Table 2. Select Optical Data for Phosphonate Compounds

\begin{tabular}{|l|l|l|l|l|l|}
\hline \multicolumn{1}{|c|}{ Compound } & \multicolumn{1}{|c|}{ Solvent } & \multicolumn{1}{|c|}{$\begin{array}{c}\lambda_{\text {ex }} \\
(\mathrm{nm})\end{array}$} & \multicolumn{1}{c|}{$\begin{array}{c}\lambda_{\mathrm{em}} \\
(\mathrm{nm})\end{array}$} & \multicolumn{1}{c|}{$\begin{array}{c}\Delta^{\mathrm{c}} \\
(\mathrm{nm})\end{array}$} & \multicolumn{1}{|c|}{$\begin{array}{c}\text { Quantum } \text { Yield }^{\mathrm{d}} \\
\Phi( \pm 10 \%)\end{array}$} \\
\hline Anthracene $^{\mathrm{a}}$ & - & 350 & 396 & 46 & 33 \\
\hline AntPet $^{\mathrm{a}}$ & dichloromethane & 368 & 421 & 53 & 33.2 \\
\hline AntPOH & dimethyl sulfoxide & 362 & 415 & 53 & 40.1 \\
\hline AntPONa & water & 361 & 409 & 49 & - \\
\hline Naphthalene & - & 275 & 321 & 46 & 23 \\
\hline NapPet & dichloromethane & 277 & 341 & 64 & 15.6 \\
\hline NapPOH & dimethyl sulfoxide & 278 & 340 & 62 & 22.3 \\
\hline NapPONa & water & 276 & 337 & 59 & - \\
\hline
\end{tabular}




\begin{tabular}{|l|l|l|l|l|l|}
\hline DecNapPet & dichloromethane & 281 & 353 & 66 & 13.9 \\
\hline DecNapPOH & dimethyl sulfoxide & 280 & 355 & 79 & 24.8 \\
\hline DecNapPONa & water & 275 & 357 & 81 & - \\
\hline
\end{tabular}

[a] From Reference 23 [b] From Reference 10 [c] Stoke's shift [d] Calculated using O-AntPpd (AntPxx series) and naphthalene (NapPxx and DecNapPxx series) as reference

The emission profiles and quantum efficiencies of the compounds were measured at concentrations well below their CMCs (see CMC section below). The relevant optical data are reported in Table R3-1 and fluorescence spectra are given in Figure 2. The changes in the aryl group have significant effects on the emission maxima while the other phosphorus substituents and solvent have little effect. The quantum efficiencies were measured for all the phosphonic acids and phosphonate esters using the corresponding arenes as references. Only minor deviations from the quantum yield of the parent fluorophore were observed in the compounds. For all the compounds the quantum yield is larger for the phosphonic acid than for the corresponding phosphonate ester. This is likely due to the loss of nonradiative decay pathways from the removal of the alkyl arms. ${ }^{23}$
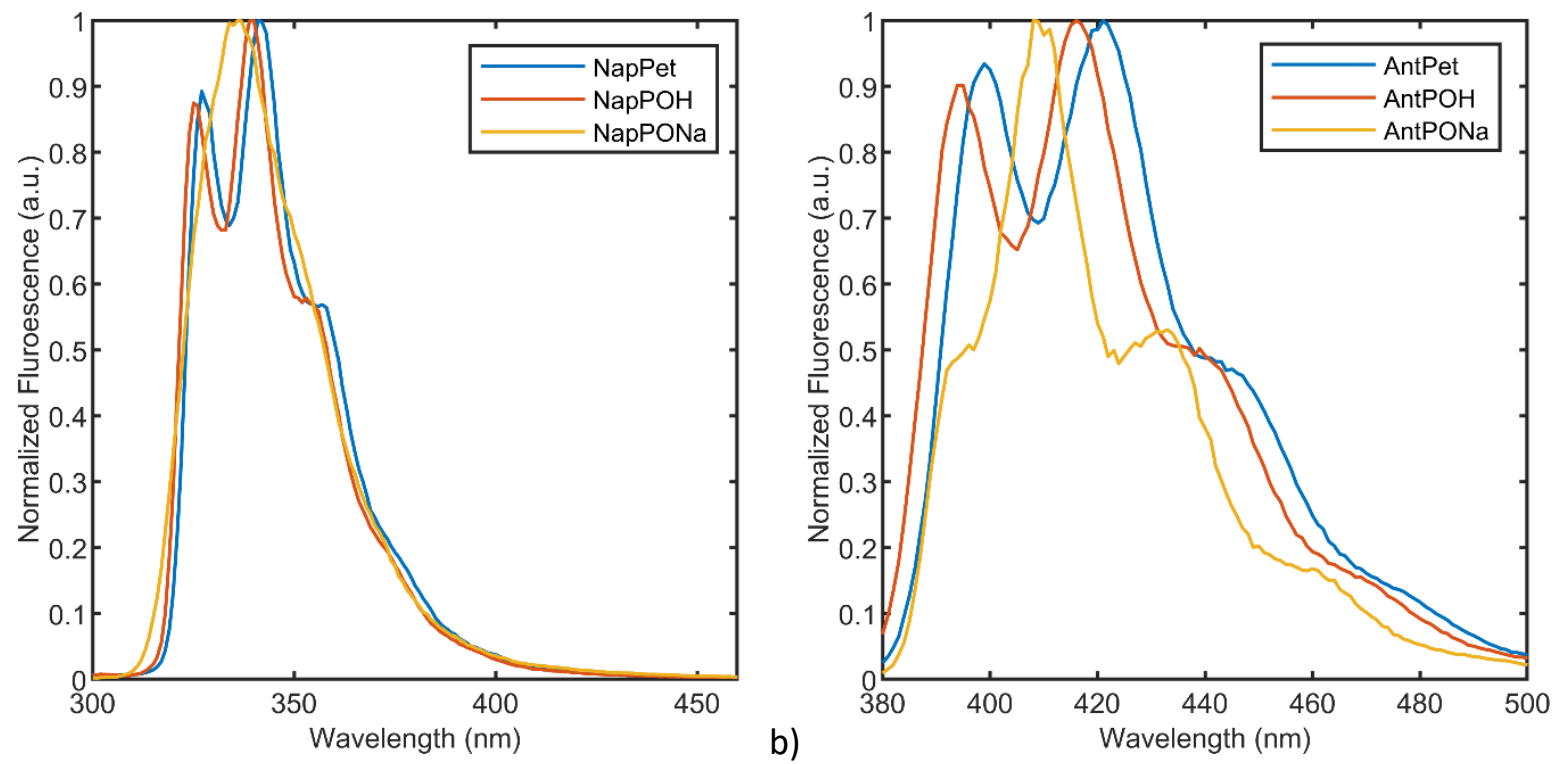


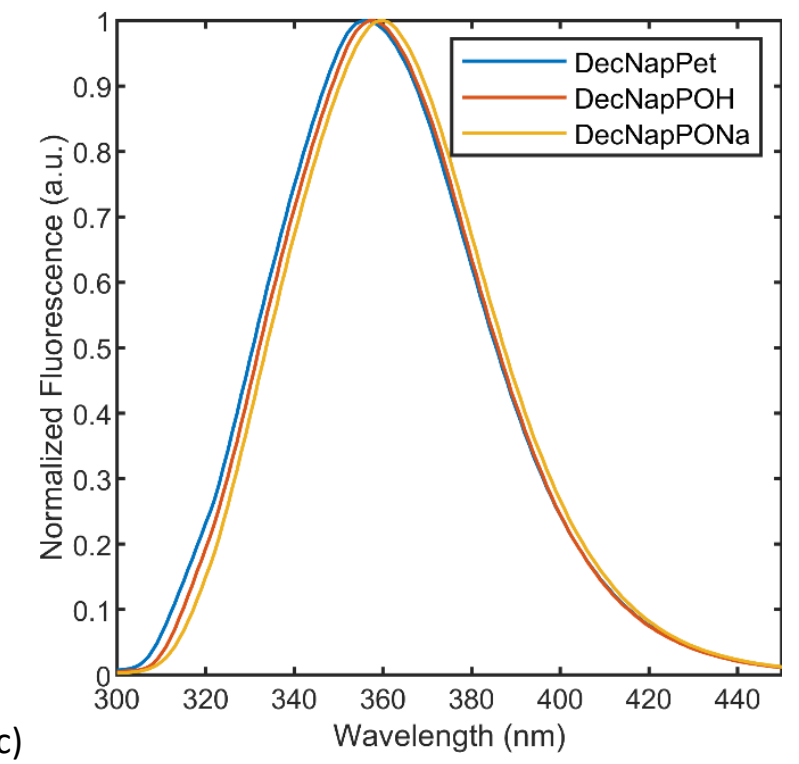

Figure 2. Fluorescence profiles of a) NapPxx, b) AntPxx, and c) DecNapPxx

\section{Determination of Critical Micelle Concentration}

\section{NMR Titrations}

The transition from monomer to micelle changes the chemical environment of the phosphorus nuclei. This suggests that it should be possible to estimate the concentration at which micelles begin to form in solution (critical micelle concentration or $\mathrm{CMC}$ ), and theoretically the point at which radioluminescence should increase, using ${ }^{31} \mathrm{P}\left\{{ }^{1} \mathrm{H}\right\}$ NMR spectroscopy.

A rough estimate of the $\mathrm{CMC}$ can be determined by the fit of two sets of points around the first change in ${ }^{31} \mathrm{P}\left\{{ }^{1} \mathrm{H}\right\}$ NMR chemical shift as the concentration of the salt is increased. ${ }^{26,27}$ The plots for each salt and the fits are given in Figure 3.
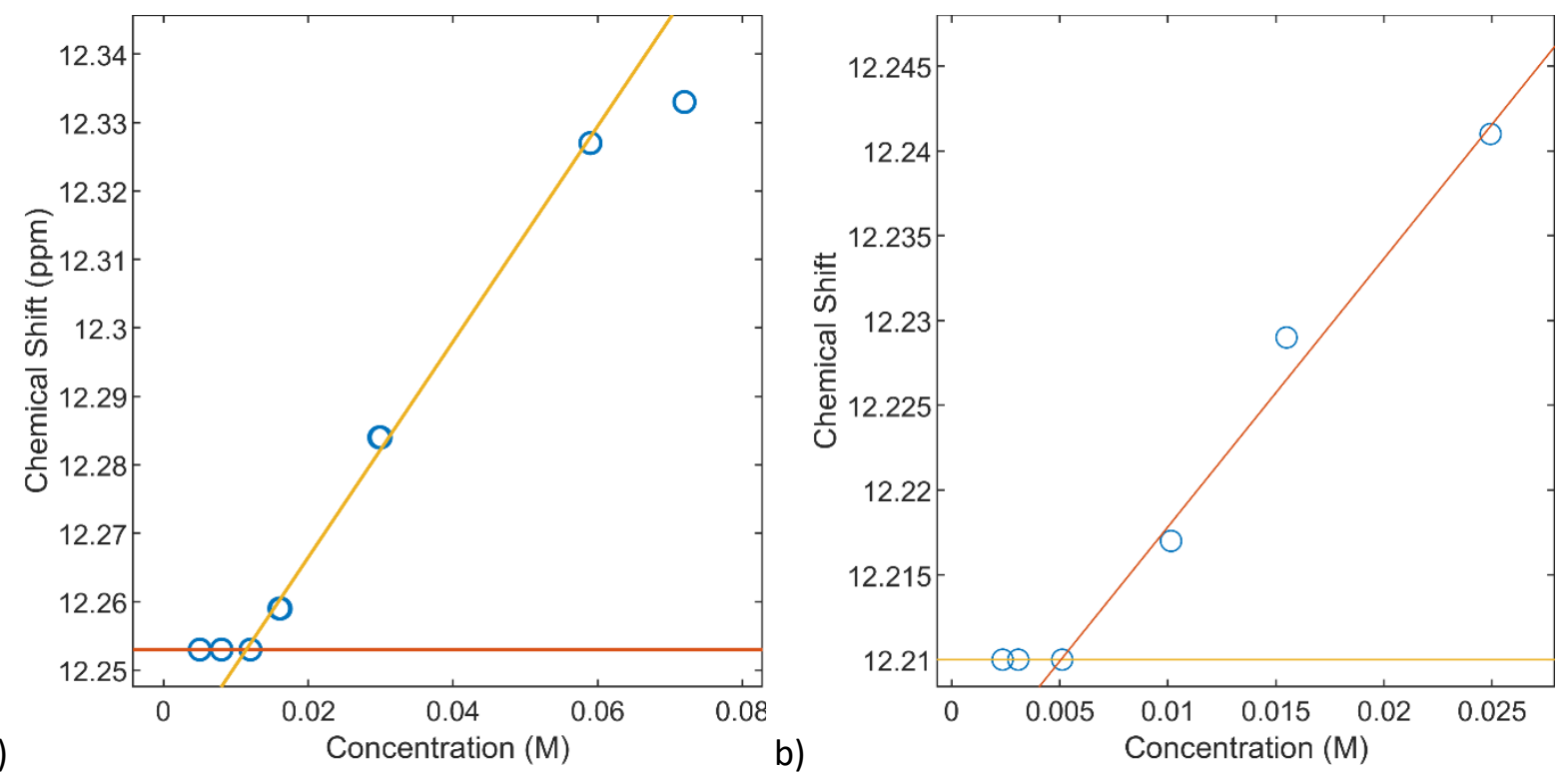


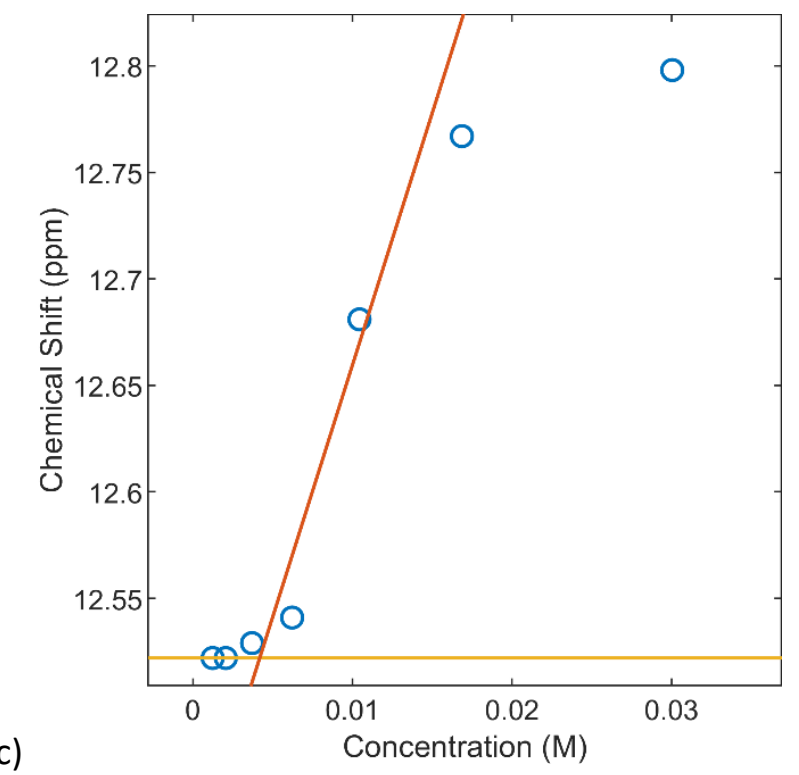

Figure 3. ${ }^{31} \mathrm{P}$ Chemical Shifts and best fit lines of a series of dilutions of a) NapPONa b) AntPONa c) DecNapPONa

Interestingly all the compounds examined exhibited an abrupt change in the ${ }^{31} \mathrm{P}$ NMR spectrum, indicating all may form micelles. A few trends are observed for these estimated CMCs. The critical micelle concentration decreases following NapPONa $>$ AntPONa $>$ DecNapPONa. This indicates the length of the hydrophobic tail increases the CMC decreases, following the general rule for surfactants. ${ }^{28}$, 29

The transition from monomer to micelle in solution at room temperature is a fast process on the NMR time scale, and the observed ${ }^{31} \mathrm{P}$ resonance is a weighted average of the two states. ${ }^{26,27}$ Below the CMC, only monomer is present and the signal observed is wholly dependent on the signal of the monomer. Above the $\mathrm{CMC}$, the signal observed follows equation 1 below, where $\delta_{\text {obs }}, \delta_{\text {mon }}, \delta_{\text {mic }}$, and $C_{t}$ represent the signal observed, the signal of the micelle, the signal of the monomer, and the concentration of salt respectively, if the $\delta_{\text {mic }}$ is independent of concentration.

$$
\text { 1) } \delta_{o b s}=\delta_{m i c}-\frac{C M C}{C_{t}}\left(\delta_{m i c}-\delta_{m o n}\right)
$$

The values for $\delta_{\text {mon, }}, \delta_{\text {mic }}$ and the CMC can be approximated by non-linear least squares fitting of the above equation using data points only after the estimated CMC. The observed lowest chemical shift and the estimated CMC from Figure 3 were used as initial guesses in the fitting. The calculated parameters are given in Table 3. The model fits the naphthalene-based salts well, but not the anthracene-based salts as plotted in Figure 4. Examination of the experimental plots of ${ }^{31} \mathrm{P}$ signal against the concentration reveals the chemical shifts in AntPONa and TerPONa increases in almost a linear fashion (supplemental info) and thus $\delta_{\text {mic }}$ is dependent on concentration. Crystal structures from our previous work into anthracene phosphonate esters indicate extensive $\pi$-stacking in the solid state. ${ }^{23}$ It could be possible the longer $\pi$-systems found in AntPONa form larger networks in the micellular state, and that the $\delta_{\text {mic }}$ depends on the size of the network.

Table 3. Calculated parameters of $\delta_{\text {mon }}, \delta_{\text {mic }}$ and the $\mathrm{CMC}$ from experimental data and Equation 1 


\begin{tabular}{|l|l|l|l|l|l|}
\hline Compound & \multicolumn{1}{|l|}{$\begin{array}{c}\text { Initial CMC Estimate } \\
\text { (from Figure R2-2) }\end{array}$} & $\begin{array}{l}\text { Critical Micelle } \\
\text { Concentration }\end{array}$ & $\begin{array}{c}\delta_{\text {mon }} \\
\mathrm{ppm}\end{array}$ & \multicolumn{1}{|c|}{$\begin{array}{c}\delta_{\text {mic }} \\
\mathrm{ppm}\end{array}$} & $\mathrm{R}^{2}$ \\
\hline AntPONa & 5.0 & - & - & - & - \\
\hline NapPONa & 14.4 & 14.8 & 12.24 & 12.36 & 0.9345 \\
\hline DecNapPONa & 4.2 & 6.5 & 12.56 & 12.86 & 0.9905 \\
\hline
\end{tabular}
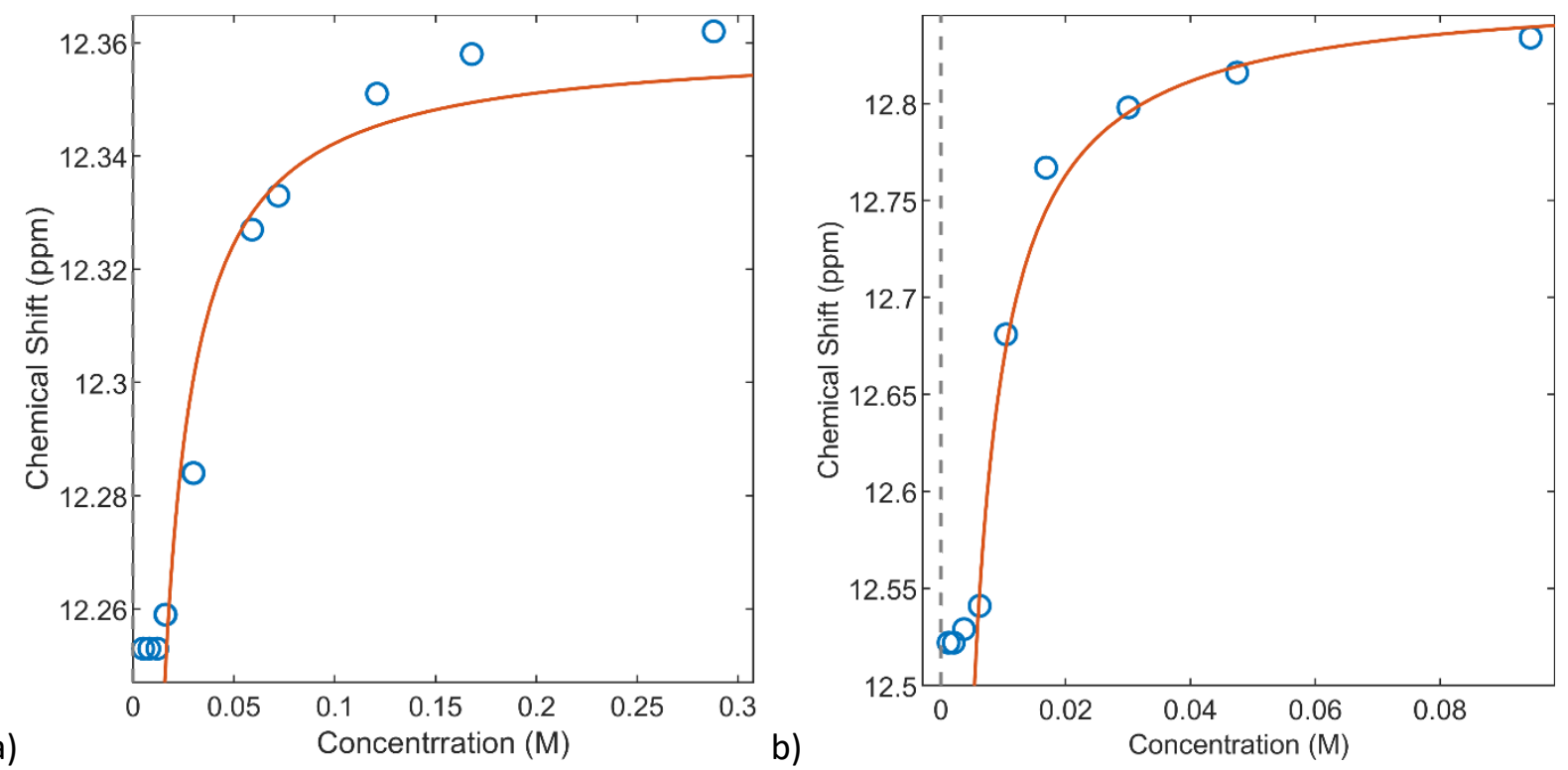

Figure 4. Plot of experimental data and model function above the CMC for a) NapPONa, b) DecNapPONa

\section{Fluorescence Titrations}

Another common method for $\mathrm{CMC}$ determination is through the use of fluorescence of either an internal or external probe. ${ }^{19}$ All the arylphosphonate salts are fluorophores and may be used as internal probes. A series of dilutions, starting at concentrations above the NMR calculated CMC and ending at concentrations below it, was prepared for each phosphonate salt, and the emission recorded when excited at the maximum absorbance for the monomer (Figure 5). In all cases, an increase in fluorescence intensity was observed as the salts were diluted. Furthermore, below the CMC the fluorescence increased at an even greater rate with dilution. There are two valid explanations for this phenomenon: First, arene fluorophores are highly susceptible to inner-filter effects and self-quenching at high concentrations. ${ }^{30}$ We have recently measured the concentrations of maximum emission intensity in anthracene-based polymers to be lower than the CMCs determined here, indicating large quenching effects are present at the concentrations used in the fluorescence titrations. ${ }^{16}$ Secondly, the stacking of the aromatic rings in the micellular structure could open a secondary emission, whose excitation lies on top of the emission of the monomer. This effect is observed in two of the phosphonate salts, NapPONa and AntPONa (Figure 6). The secondary emission observed in AntPONa, as seen in Figure 6b (inset), was captured at a longer integration time to highlight its concentration dependence. As the concentration of the salt decreases, the blue emission increases in intensity while the secondary emission decreases 
simultaneously. The secondary emission appears more intense relative to the primary emission in NapPONa because there is little overlap in the profiles. The loss of these secondary emission profiles as the micelle concentration decreases indicates there may be FRET-like interactions between the monomeric and micellular forms of the salt. ${ }^{31}$ It is possible that DecNapPONa also experiences this, but the effect is obscured by inner filter effects.
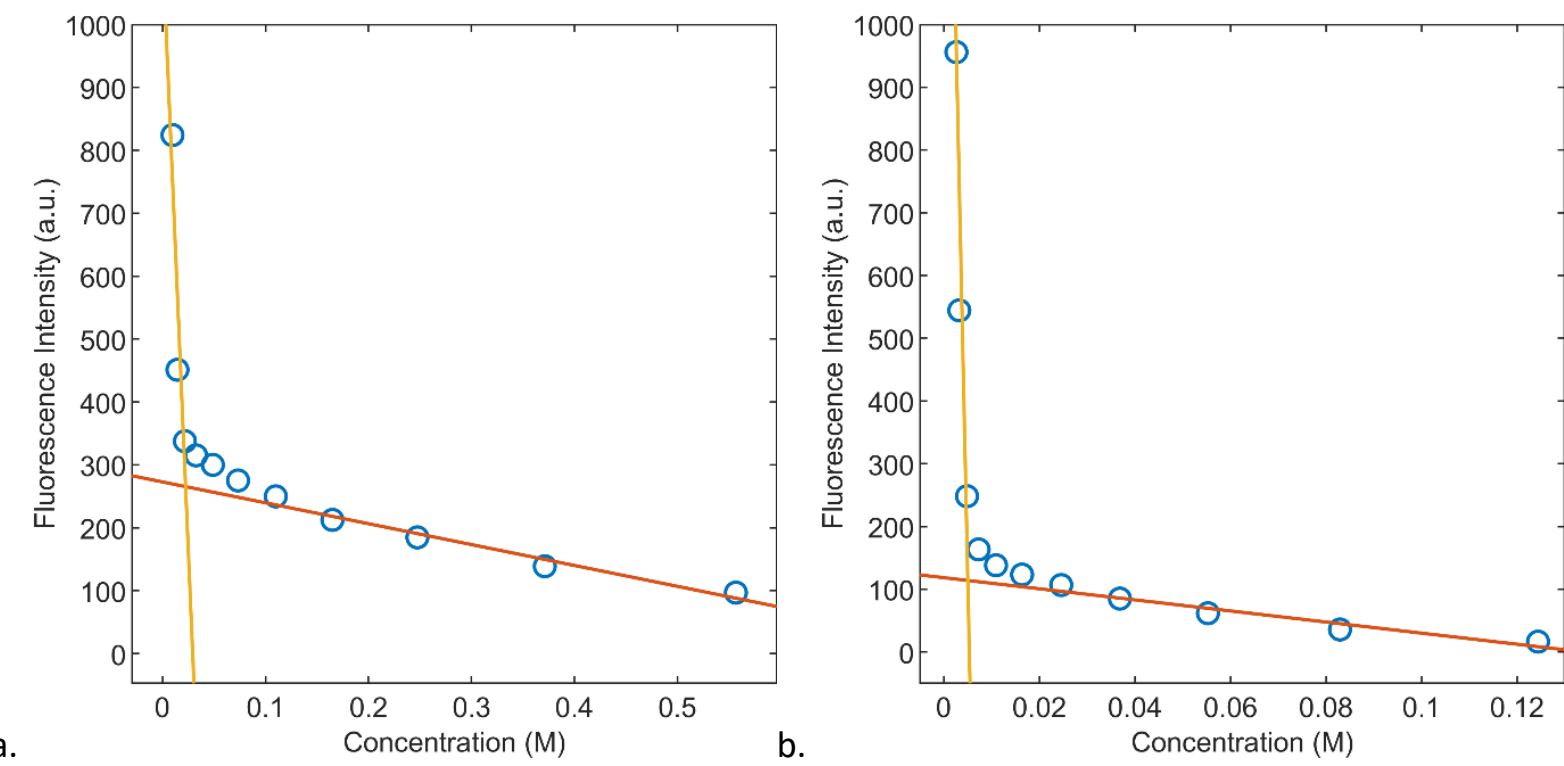

a.

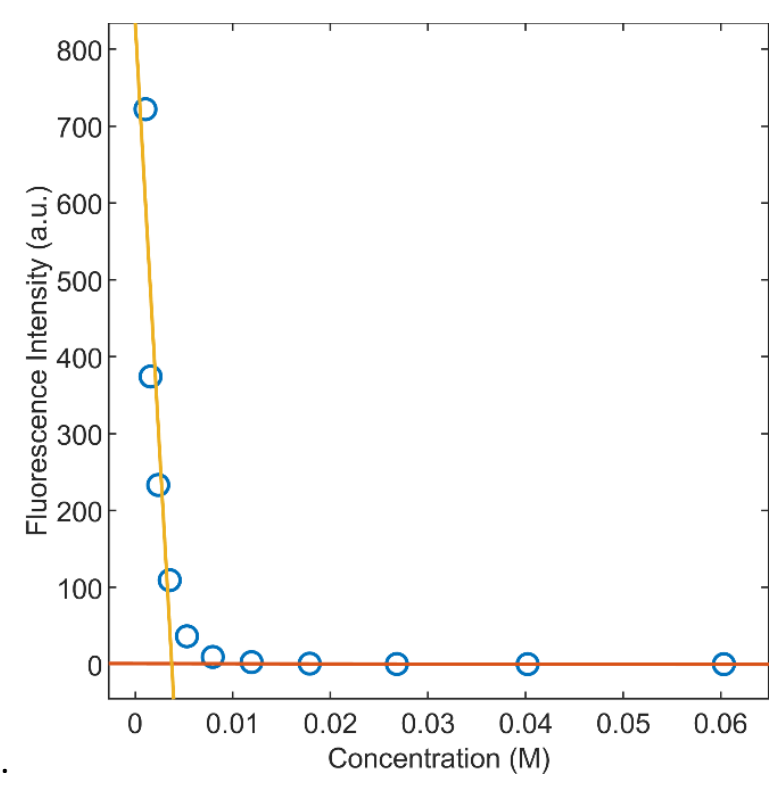

Figure 5. Fluorescence change over a series of dilutions and calculated fits for a. AntPONa b. NapPONa c. DecNapPONa

An estimate of the $\mathrm{CMC}$ was determined by drawing two best-fit lines for the first and last three points on either side of the sharp increase in fluorescence intensity. The concentration at which the two lines intersect was determined to be the $\mathrm{CMC}$, which is reported in Table 4 below. Despite the factors discussed above, good agreement of the CMC between methods was observed in all the compounds. Linear alkyl benzene sulfonates typically have $\mathrm{CMC}$ values around $2.8 \mathrm{mM}$, indicating more monomer is 
present in these solutions of arylphosphonates. ${ }^{19}$ Additionally, the aggregation number (or molecules per micelle) is inversely related to the $\mathrm{CMC}$, suggesting these arylphosphonate salts are smaller than a typical LAS micelle. ${ }^{32}$

Table 4. Comparison of calculated CMC by two techniques.

\begin{tabular}{|l|c|c|}
\hline \multicolumn{1}{|c|}{ Compound } & $\begin{array}{c}\text { NMR } \\
(\mathrm{mM})\end{array}$ & $\begin{array}{c}\text { Fluorescence } \\
(\mathrm{mM})\end{array}$ \\
\hline NapPONa & 14.7 & 14.6 \\
\hline AntPONa & $5.0^{\mathrm{a}}$ & 5.0 \\
\hline DecNapPONa & 6.5 & 3.7 \\
\hline LAS $^{\mathrm{b}}$ & - & 2.8 \\
\hline
\end{tabular}

[a] Value taken from initial CMC measurement [b] From Reference 20
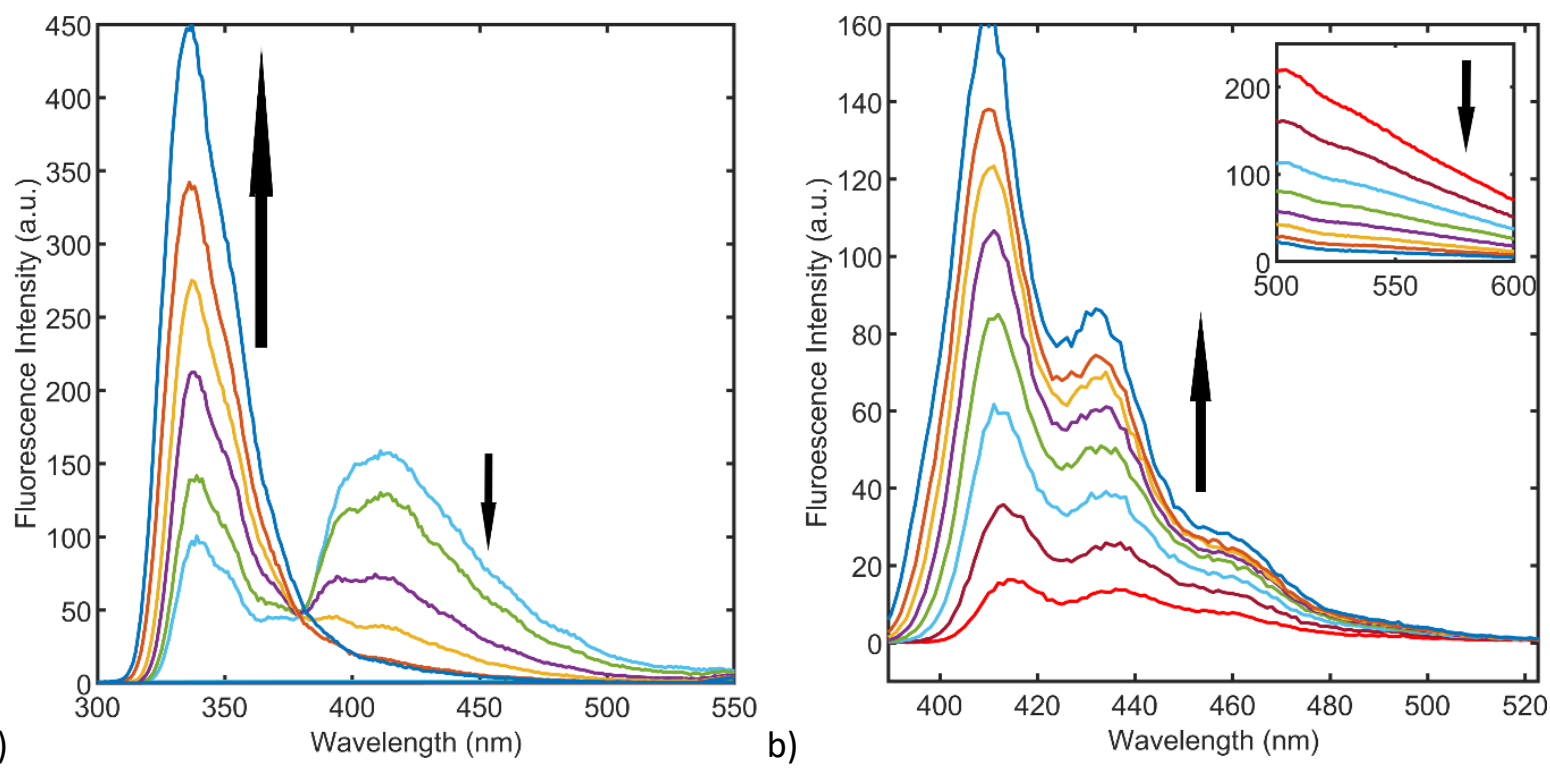

Figure 6. Emission profiles of NapPONa (a) and AntPONa (b) over a series of dilutions. Arrow indicates decreasing concentration.

Solid State Fluroescence ${ }^{r 5}$ 

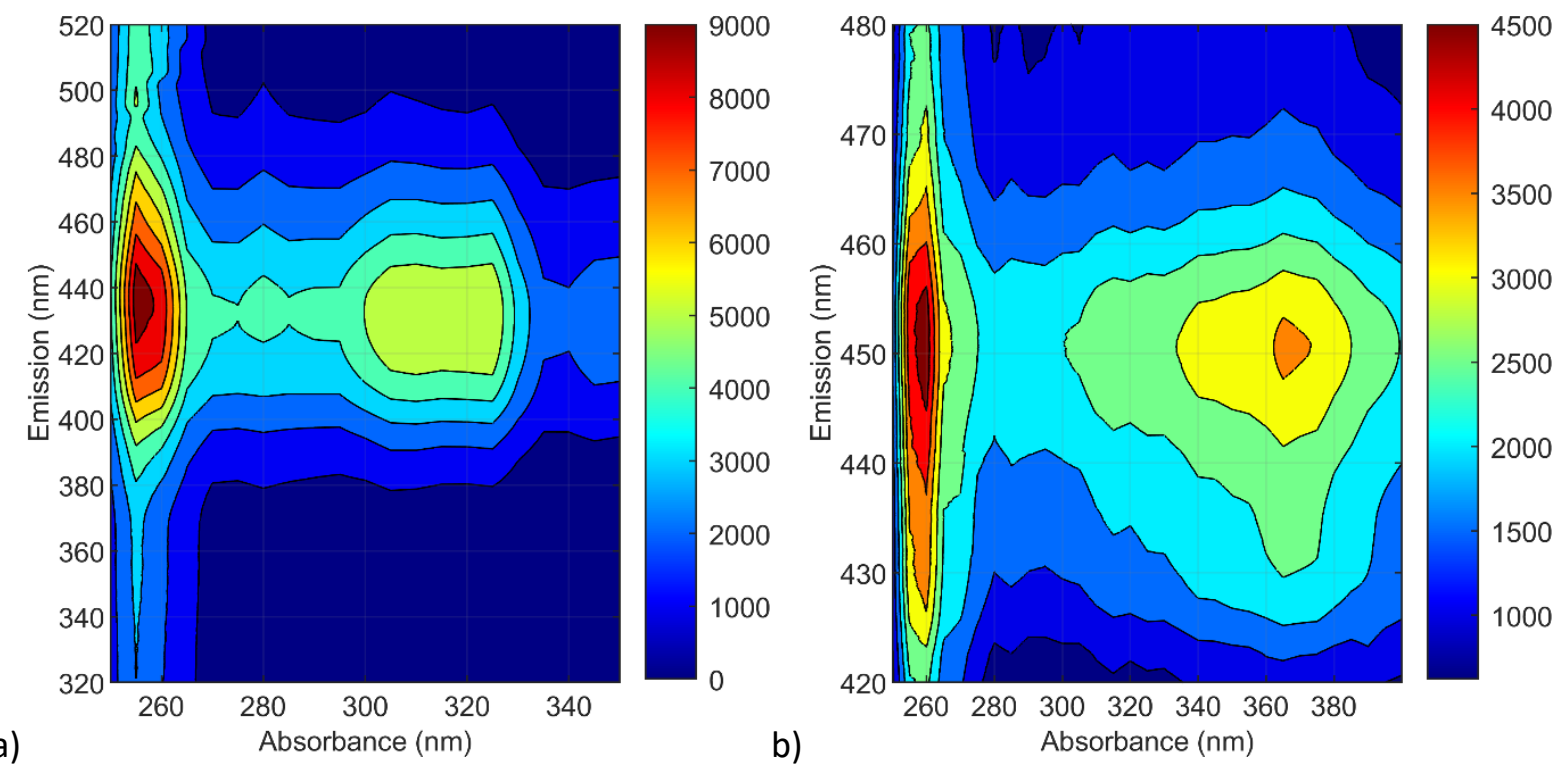

Figure 7. 2D spectra of a) NapPONa b) AntPONa

The fluorescence results described above indicate pi-stacking in the micelles of phosphonate salts leads to a secondary emission red-shifted from the primary. This secondary emission could indicate a conservation of optical properties between a micelle in solution and a crystalline sample. Previous work from our group and others has shown that the solid state emission of a fluorophore is generally red shifted from its solution state, due to aromatic stacking effects. ${ }^{33,23}$ To observe these effects, 2-D plots of the absorbance vs. the photoluminescence were recorded. ${ }^{34-36}$ The nature of this experiment required bright samples, therefore only NapPONa, AntPONa (Figure 7). Both compounds examined exhibited a redshift from the solution state, and a strong far UV $(255 \mathrm{~nm}$ ) absorbance with a weaker near UV (300$340 \mathrm{~nm}$ ) absorbance. The absorbance profile of AntPONa is unchanged from the solution state, and the emission is redshifted by about $30 \mathrm{~nm}$. The more interesting results come from NapPONa. In this compound the near UV absorbance is redshifted from the solution state and lies directly on top of the emission of the monomer. In solid NapPONa, this absorbance leads to an emission around $440 \mathrm{~nm}$, perfectly matching the emission of the solution when excited at $336 \mathrm{~nm}$. This suggests the $\pi$ system arrangement in a micelle closely matches the crystalline $\pi$-stacking in solid form, and supports the discrepancies observed between the NMR and fluorescence CMC methods. In solution, a secondary emission is observed in AntPONa, but it is very weak compared to the main emission feature and is not correlated with the solid-state emission. This suggests that the structure of the micellular AntPONa does not resemble the solid-state.

\section{Radioluminescence ${ }^{r 6}$}

There are three distinct subcategories under the heading of organic scintillators: crystalline, solution state, and plastic. ${ }^{37,22}$ Of these, crystalline scintillators are the brightest of the group due to the longrange aromatic interactions achieved by $\pi$-stacking. For solution-state and plastic scintillators, radioluminescence relies on initial capture by the solvent or polymer matrix (usually aromatic, i.e. toluene or polystyrene), followed by transfer to the scintillator. This leads to lower emissions due to the conversions involved in the mechanism. To date, there are few references that demonstrate the 
scintillation ability of water-based organic compounds. From the above fluorescence studies, the micelles exhibit some solid-state characteristics that may enhance radioluminescence.. All solid samples were ground into a fine powder using a mortar and pestle to ensure a physical uniformity, as crystal shape and size can affect fluorescence, ${ }^{38,39}$ and plots of the radioluminescence are shown in Figure 8.

a)

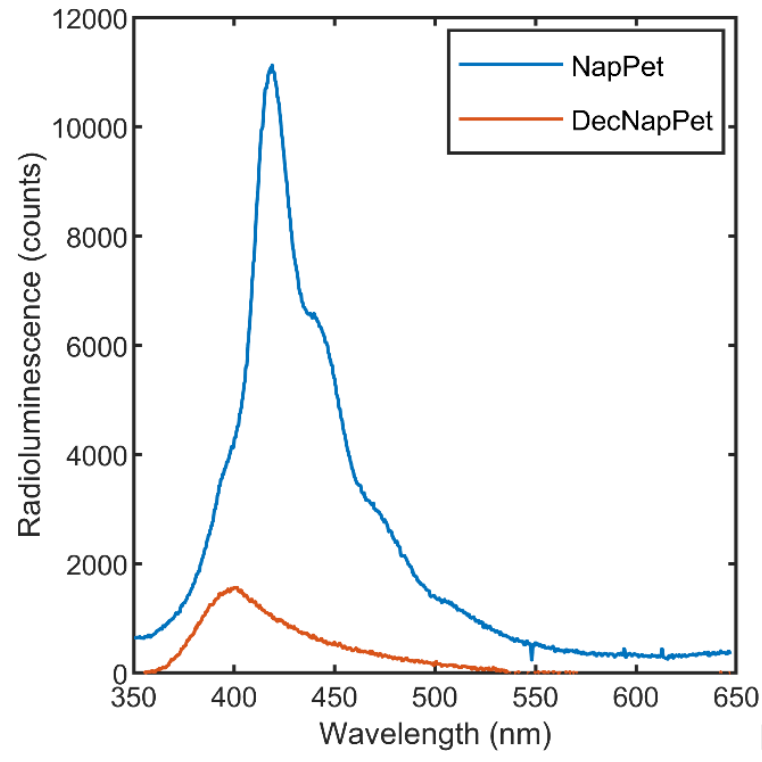

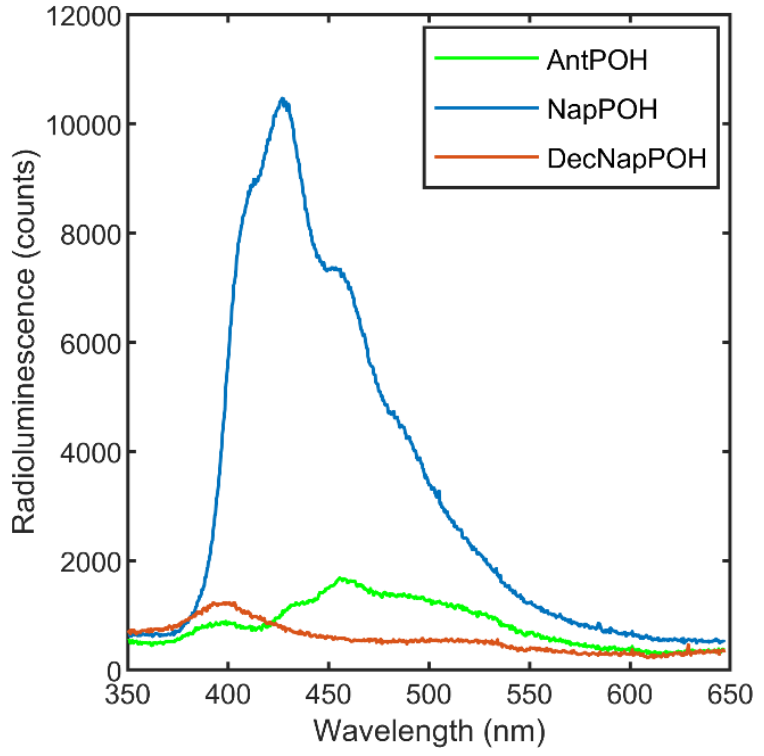

b)

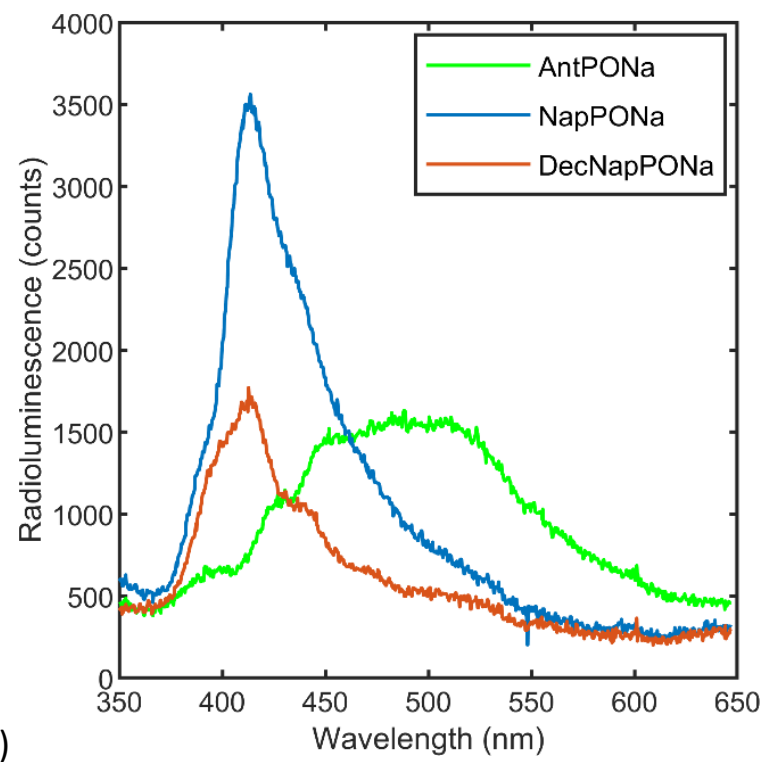

c)

Figure 8. Radioluminescence of Solids a. et b. OH c. $\mathrm{Na}$

In all cases, the x-ray excited emission was redshifted from the solution-state UV-excited emissions as expected due to the mechanism of radioluminescence in organic compounds, where $75 \%$ of ion recombinations populate the triplet state ${ }^{40}$ For the phosphonate ester series, NapPOH exhibited the greatest output of the new compounds (Data from Figure 8 detailed in Table 5). We have previously demonstrated that AntPet is an excellent x-ray induced scintillator and had the greatest emissive yield 
relative to anthracene..$^{23}$ Interestingly, this strength does not carry over to the phosphonic acid and salt forms. Our previous work indicates that crystal structure of these aromatic phosphonates can greatly affect the radioluminescence properties. It could be that AntPOH and AntPONa have largely different solid-state structures that do not enhance radioluminescence. The naphthalene-based phosphonates NapPxx exhibit the greatest radioluminescence yields of the new compounds reported here; however, AntPet still remains the most emissive compound our group has developed. ${ }^{23}$ It is not surprising that the DecNapPxx series exhibited the lowest radioluminescence yields. The long aliphatic tail is not aromatic and probably disrupts the $\pi$-stacking in the solid state. Transformation to the sodium salt also negatively affects the radioluminescence of the solids, especially NapPxx. Sodium is a relatively low $Z$ atom, using cesium hydroxide in the salt synthesis could increase the $\mathrm{x}$-ray absorption of the material in the solid state.

Table 5. Select Radioluminescence Details

\begin{tabular}{|l|c|c|c|c|}
\hline Compound & $\begin{array}{c}\text { UV Stimulated } \\
\text { Emission } \\
\text { Wavelength } \\
(\mathrm{nm})\end{array}$ & $\begin{array}{c}\text { X-ray Stimulated } \\
\text { Emission } \\
\text { Wavelength } \\
(\mathrm{nm})\end{array}$ & $\begin{array}{c}\text { Emission Shift } \\
(\mathrm{nm})\end{array}$ & $\begin{array}{c}\text { Emission Yield } \\
\text { Relative } \\
\text { Anthracene (\%) }\end{array}$ \\
\hline Anthracene $^{\mathrm{a}}$ & 396 & 530 & 134 & - \\
\hline AntPet $^{\mathrm{a}}$ & 421 & 580 & 159 & 236 \\
\hline AntPOH & 415 & 452 & 37 & 19 \\
\hline AntPONa & 409 & 485 & 76 & 22 \\
\hline NapPet & 341 & 421 & 80 & 54 \\
\hline NapPOH & 340 & 425 & 85 & 75 \\
\hline NapPONa & 337 & 418 & 81 & 24 \\
\hline DecNapPet & 353 & 402 & 49 & 13 \\
\hline DecNapPOH & 355 & 398 & 43 & 14 \\
\hline DecNapPONa & 357 & 412 & 55 & \\
\hline
\end{tabular}

[a] From Reference 23

Of the compounds characterized above, the naphthalene-based phosphonate NapPONa demonstrated both well-defined micelle formation and exhibited strong solid-state radioluminescence across the et $\rightarrow$ $\mathrm{OH} \rightarrow \mathrm{ONa}$ range. The radioluminescence wavelength also lies directly on top of the excitation profile of ChR2, a well-studied optogenetic target. Therefore, this salt was used to determine if micelle formation lead to an enhancement of radioluminescence intensity. A solution of NapPONa at $0.12 \mathrm{M}$ was used as the stock and diluted by half four times, so the final dilution would cross into the monomer region. These dilutions were measured in a quartz cuvette in the same fashion as above, with the same settings on the $x$-ray generator and same integration time of 20s. The measured radioluminescence spectra are shown in Figure 9. The stock solution has an emission maximum slightly blue shifted from, but an order of magnitude less intense, than the salt in the solid state. The reduction in intensity could be due to two factors: the inefficient transfer of energy from the solvent to the micelle, and dilute nature of the solution as opposed to the packed solid sample. Nonetheless, a concentration dependence of radioluminescence is observed, where the emission decreases as the salt concentration (and therefore micelle concentration) is decreased. This is directly opposite the UV-induced fluorescence emission, where, as the concentration was decreased the fluorescence intensity increased as the FRET and selfquenching interactions decreased. Furthermore, almost a complete loss of measurable 
radioluminescence is seen as the salt transitions from a micelle to a monomer form, showing the monomer possesses little to no radioluminescent ability. This finding indicates the $\pi$-stacking of the aromatic rings in micellular form may be a critical factor in radioluminescence.

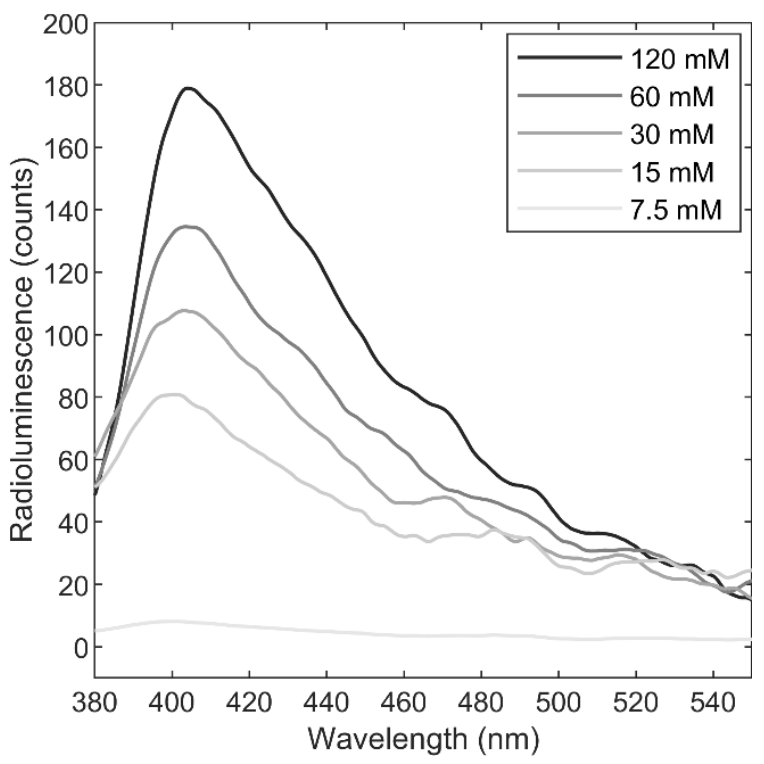

Figure 9. Radioluminescence of phosphonate salt NapPONa at five different concentrations.

\section{Conclusion}

A series of amphiphilic aryl-phosphonate salts have been synthesized in moderate to high yields. These salts were prepared to investigate the mechanism of $\mathrm{x}$-ray induced radioluminescence in water and determine if micelle formation was responsible for the enhancement of emission intensity. Two separate techniques, ${ }^{31} \mathrm{P}$ NMR and fluorescence titrations, were used to determine micelle formation in water. Micelle formation was observed in amphiphilic DecNapPONa, which is structurally similar to LAS. Interestingly, AntPONa and NapPONa also showed micelle formation in water, despite the absence of a long hydrophobic tail. The naphthalene-based compounds fit the NMR micelle formation model well, indicating discreet spherical micelles being formed. The anthracene-based salt does not fit the model, suggesting an aggregate structure dependent on concentration.

Fluorescence titrations as an alternative $\mathrm{CMC}$ determination method revealed secondary emission characteristics in NapPONa and AntPONa. The alignment of the aromatic rings in the micelle structure likely produce an emission redshifted from the emission of the monomer. The excitation wavelength of the secondary emission lies on top of the primary emission wavelength, indicating FRET-like interactions between monomer and micelle at concentrations above the CMC. Solid-state fluorescence of NapPONa reveals an absorption for the solid compound that matches the excitation for the micellular form in water, which suggests the aromatic interactions in the micellular aggregates mimics solid-state interactions.

The radioluminescence of the solid compounds were measured using soft ( $50 \mathrm{kV}) \mathrm{x}$-rays. All the compounds exhibited moderate emission intensities with varied emission wavelengths, showing the radioluminescence can be tuned for specific applications through choice of the parent fluorophore and phosphorous substitution. The NapPxx series of compounds performed the best of the new 
compounds; therefore, the NapPONa salt was used to observe if micelle formation could enhance radioluminescence. The radioluminescence of a series of dilutions of the salt revealed two findings: the radioluminescent output is concentration dependent, and a complete loss of emission is observed as the concentration is diluted beyond the $\mathrm{CMC}$ highlighting that aromatic interactions in the micelle are a necessary component of the scintillation mechanism in water. Finally, the radioluminescence emission wavelength of micellular NapPONa overlaps well with the excitation spectrum of channelrhodopsin-2 (ChR2) suggesting the combination of the micelles with ChR2-expressing neuronal cells could make for a useful optogenetic tool. ${ }^{1}$

\section{Experimental}

All procedures were carried out under a zero-grade $\mathrm{N}_{2}$ atmosphere using standard Schlenk-line techniques unless otherwise noted. Unless otherwise noted all commercially available solvents and chemicals were purchased from Fisher Scientific or TCl America and used as received. Dichloromethane was distilled from calcium hydride and stored over $4 \AA$ molecular sieves under $\mathrm{N}_{2}$ until use. The ester AntPet was synthesized according to literature procedure. ${ }^{23}$ The ${ }^{1} \mathrm{H} N M R$ and ${ }^{13} \mathrm{C}\left\{{ }^{1} \mathrm{H}\right\}$ NMR spectra were referenced to internal tetramethylsilane (TMS). Assignments were based on $2 \mathrm{D}$ NMR spectra $\left({ }^{1} \mathrm{H}-{ }^{13} \mathrm{C}\right.$ $\mathrm{HSQC},{ }^{1} \mathrm{H}-{ }^{1} \mathrm{H}$ COSY, and $\left.{ }^{1} \mathrm{H}-{ }^{13} \mathrm{C} \mathrm{HMBC}\right)$. All deuterated solvents were obtained from Cambridge Isotope Laboratories, Inc. All chemical shifts $(\delta)$ are in parts per million (ppm). The digital resolutions of the ${ }^{1} \mathrm{H}$, ${ }^{13} \mathrm{C}\left\{{ }^{1} \mathrm{H}\right\}$, and ${ }^{31} \mathrm{P}$ were \pm 0.01 , and \pm 0.02 and $\pm 0.01 \mathrm{ppm}$, respectively.

\section{$\mathrm{DecNapBr}$}

A solution of 6-bromo-2-naphthol ( $3.456 \mathrm{~g}, 15.50 \mathrm{mmol}), 1$-bromodecane $(3.427 \mathrm{~g}, 15.50 \mathrm{mmol}$ ) and potassium carbonate $(5 \mathrm{eq})$ in $150 \mathrm{~mL}$ of acetone heated at reflux for $24 \mathrm{hr}$. Then the solvent was removed under reduced pressure on a rotovap. The solid residue was treated with DCM and filtered. The filtrate was washed three times with water. Removal of the DCM under reduced pressure on a rotovap yielded the crude product. This was purified by a modified column chromatography procedure. Crude product was wet loaded onto a short path of silica gel. Impurities were passed first, followed by the pure product using a gradient of hexanes to hexanes/ethyl acetate (1:1). The solvents were removed under vacuum to afford DecNapBr as a white powder (3.642 g, 64.69\%).

\section{General Modified Arbuzov Procedure}

A general procedure for the modified Arbuzov procedure is as follows: Bromoarene (1 eq.), triethylphosphite (1 eq), and $\mathrm{NiBr}$ (cat.) were dissolved in $75 \mathrm{~mL}$ of mesitylene in a Schlenk flask fitted with stir bar and reflux condenser. This solution was refluxed for $20 \mathrm{hr}$. Any precipitates were removed by filtration through Celite. Solvents were then removed with a rotovap under reduced pressure. Crude product was purified by column chromatography.

\section{NapPet:}

2-Bromonapthalene $(3.08 \mathrm{~g}, 14.9 \mathrm{mmol})$. Triethylphosphite $(2.47 \mathrm{~g}, 14.9 \mathrm{mmol})$. Crude liquid product was wet loaded onto silica with $3 \mathrm{~mL}$ of eluent. Column was packed in a 50:1 silica:product ratio using 2:5 hexanes:EtOAc as eluent. Pure NapPet was obtained as a pale yellow oil (1.88 g, 47.9\%). ${ }^{31} \mathrm{P}\left\{{ }^{1} \mathrm{H}\right\} \mathrm{NMR}$ $\left(162 \mathrm{MHz} ; \mathrm{CDCl}_{3}\right): \delta 20.34 .{ }^{1} \mathrm{H} \mathrm{NMR}\left(700 \mathrm{MHz} ; \mathrm{CDCl}_{3}\right): \delta \mathbf{~ H - 1} 8.42\left(\mathrm{~d}, 1 \mathrm{H},\left.\right|^{3} J_{\mathrm{HH}} \mathrm{l}=15.5 \mathrm{~Hz}\right), \mathbf{H}-97.92(\mathrm{~d}$, $\left.1 \mathrm{H},\left|{ }^{3} J_{\mathrm{HH}}\right|=8.0 \mathrm{~Hz}\right), \mathbf{H}-47.90\left(\mathrm{dd}, 1 \mathrm{H},\left.\right|^{3} J_{\mathrm{HH}}|=8.6 \mathrm{~Hz},|^{4} J_{\mathrm{PH}} \mid=4.1 \mathrm{~Hz}\right), \mathbf{H}-67.86\left(\mathrm{~d}, 1 \mathrm{H},\left.\right|^{3} J_{\mathrm{HH}} \mid=8.2 \mathrm{~Hz}\right), \mathbf{H}-$ 
$37.75\left(\mathrm{ddd}, 1 \mathrm{H},\left.\right|^{3} \mathrm{JHH}_{\mathrm{HH}}|=8.4 \mathrm{~Hz},|^{3} \mathrm{~J}_{\mathrm{PH}}|=11.0 \mathrm{~Hz},|^{4} \mathrm{~J}_{\mathrm{HH}} \mid=1.2 \mathrm{~Hz}\right), \mathbf{H}-\mathbf{7} 7.58(\mathrm{~m}, 1 \mathrm{H}), \mathbf{H}-\mathbf{8} 7.54(\mathrm{~m}, \mathbf{H}), \mathbf{H}-$ $114.13(\mathrm{~m}, 2 \mathrm{H}), \mathbf{H}-121.33\left(\mathrm{t}, 1 \mathrm{H},\left.\right|^{3} J_{\mathrm{HH}} \mid=7.1 \mathrm{~Hz}\right) .{ }^{13} \mathrm{C}\left\{{ }^{1} \mathrm{H}\right\}$ NMR $\left(175 \mathrm{MHz} ; \mathrm{CDCl}_{3}\right): \delta \mathrm{C}-5135.11\left(\mathrm{~d},\left.\right|^{4} J_{\mathrm{CP}} \mid=\right.$ $2.5 \mathrm{~Hz}), \mathrm{C}-1134.18\left(\mathrm{~d},\left.\right|^{2} J_{\mathrm{CP}} \mid=10.2 \mathrm{~Hz}\right), \mathrm{C}-10132.45\left(\mathrm{~d},\left.\right|^{3} \mathrm{~J}_{\mathrm{CP}} \mid=19.0 \mathrm{~Hz}\right), \mathrm{C}-9129.07(\mathrm{~s}), \mathrm{C}-4128.50$ (d, $\left.\right|^{3} J_{\mathrm{CP}} \mid=14.0 \mathrm{~Hz}$ ), C-7 $128.41(\mathrm{~s}), \mathrm{C}-6128.38(\mathrm{~s}), \mathrm{C}-8127.03(\mathrm{~s}), \mathbf{C}-3126.55$ (d, $\left.\right|^{2} J_{\mathrm{CP}} \mid=8.9 \mathrm{~Hz}$ ), C-10 125.44 $\left(d,\left|{ }^{1} J_{C P}\right|=186.9 \mathrm{~Hz}\right), \mathbf{C}-1162.22\left(d,\left.\right|^{2} J_{C P} \mid=5.1 \mathrm{~Hz}\right), \mathbf{C}-1216.37\left(\mathrm{~d},\left.\right|^{3} J_{C P} \mid=7.6 \mathrm{~Hz}\right)$.

\section{DecNapPet:}

DecNapBr (1.67 g, $4.60 \mathrm{mmol})$, triethylphosphite $(0.764 \mathrm{~g}, 4.60 \mathrm{mmol})$. Crude liquid product was wet loaded onto silica with $3 \mathrm{~mL}$ of eluent. Column was packed in a 50:1 silica:product ratio using 2:5 hexanes:EtOAc as eluent. Pure DecNapPet was obtained as a pale yellow oil (1.05 g, 53.4\%). ${ }^{31} \mathrm{P}\left\{{ }^{1} \mathrm{H}\right\} \mathrm{NMR}$ $\left(162 \mathrm{MHz} ; \mathrm{CDCl}_{3}\right): \delta 21.65 .{ }^{1} \mathrm{H} \mathrm{NMR}\left(700 \mathrm{MHz} ; \mathrm{CDCl}_{3}\right): \delta \mathbf{~ H - 1} 8.32\left(\mathrm{~d}, 1 \mathrm{H},\left.\right|^{3} J_{\mathrm{HP}} \mid=15.3 \mathrm{~Hz}\right), \mathbf{H}-97.81(\mathrm{~d}$, $\left.1 \mathrm{H},\left.\right|^{3} \mathrm{~J}_{\mathrm{HH}} \mid=8.8 \mathrm{v}\right), \mathbf{H}-47.77\left(\mathrm{dd}, 1 \mathrm{H},\left.\right|^{3} \mathrm{~J}_{\mathrm{HH}}|=8.6 \mathrm{~Hz},|^{4} \mathrm{~J}_{\mathrm{PH}} \mid=4.1 \mathrm{~Hz}\right), \mathbf{H}-37.70$ (ddd, $1 \mathrm{H},\left.\right|^{3} \mathrm{~J}_{\mathrm{HH}} \mid=8.2 \mathrm{~Hz}$, $\left.\left|J_{\mathrm{HP}}\right|=8.4 \mathrm{~Hz},\left.\right|^{4} J_{\mathrm{HH}} \mid=1.5 \mathrm{~Hz}\right), \mathbf{H}-87.21\left(\mathrm{dd}, 1 \mathrm{H},\left.\right|^{3} J_{\mathrm{HH}}|=8.8 \mathrm{~Hz},|^{4} J_{H H} \mid=2.3 \mathrm{~Hz}\right), \mathbf{H}-67.13\left(\mathrm{~d}, 1 \mathrm{H},\left.\right|^{4} J_{H H} \mid=\right.$ $2.2 \mathrm{~Hz}$ ), H-11 $4.13(\mathrm{~m}, 2 \mathrm{H}), \mathbf{H}-134.09(\mathrm{~m}, 2 \mathrm{H}), \mathbf{H}-141.85(\mathrm{q}, 1 \mathrm{H}), \mathbf{H}-151.49$ (q, 1H), H-16 1.39 (q, 1H), H$121.33\left(\mathrm{t}, 1 \mathrm{H},\left.\right|^{3} J_{\mathrm{HH}} \mid=7.1 \mathrm{~Hz}\right), \mathbf{H}-17$ through H-21 1.32-1.23 (m, 10H), $\mathbf{H - 2 2} 0.88\left(\mathrm{t}, 1 \mathrm{H},\left.\right|^{3} \mathrm{JHH}_{\mathrm{HH}} \mid=7.1 \mathrm{~Hz}\right)$. ${ }^{13} \mathrm{C}\left\{{ }^{1} \mathrm{H}\right\}$ NMR $\left(175 \mathrm{MHz} ; \mathrm{CDCl}_{3}\right): \delta$ C-7 $159.20(\mathrm{~s}), \mathrm{C}-5136.85$ (d, $\left.\left|{ }^{4} J_{\mathrm{CP}}\right|=2.5 \mathrm{~Hz}\right), \mathrm{C}-1133.94\left(\mathrm{~d},\left.\right|^{2} J_{\mathrm{CP}} \mid=\right.$ 10.2 Hz), C-9 $130.58(\mathrm{~s})$, C-10 $127.89\left(\mathrm{~d},\left.\right|^{3} \mathrm{~J}_{\mathrm{CP}} \mid=16.5 \mathrm{~Hz}\right), \mathrm{C}-3127.25\left(\mathrm{~d},\left.\right|^{2} \mathrm{~J}_{\mathrm{CP}} \mid=10.2 \mathrm{~Hz}\right), \mathrm{C}-4127.23(\mathrm{~d}$, $\left.\left|J_{\mathrm{CP}}\right|=14.1 \mathrm{~Hz}\right), \mathbf{C}-2122.58\left(\mathrm{~d},\left.\right|^{1} J_{\mathrm{CP}} \mid=190.7 \mathrm{~Hz}\right), \mathbf{C}-8120.28(\mathrm{~s}), \mathbf{C}-6106.57(\mathrm{~s}), \mathbf{C}-1368.63(\mathrm{~s}), \mathbf{C}-11$ $62.22\left(\mathrm{~d},\left.\right|^{2} J_{\mathrm{CP}} \mid=5.1 \mathrm{~Hz}\right), \mathrm{C}-1429.29(\mathrm{~s}), \mathrm{C}-626.25(\mathrm{~s}), \mathrm{C}-1216.54\left(\mathrm{~d},\left.\right|^{3} J_{\mathrm{CP}} \mid=6.4 \mathrm{~Hz}\right), \mathrm{C}-16$ through C21 $32.08,29.75,29.73,29.56,29.50,22.89$ (s), C-22 14.30 (s).

\section{General Ester Cleavage Procedure:}

A general procedure for the cleavage of the phosphonate ester is as follows: Arylphosphonate (1 eq) was dissolved in $50 \mathrm{~mL}$ of dry DCM in a Schlenk flask. Bromotrimethylsilane ( $2.5 \mathrm{eq}$ ) was added via syringe and mixture was allowed to stir for 20 hours. Solvents were removed under reduced pressure with a rotovap, followed by immediate addition of methanol. Resulting solution was allowed to stir for 1 hour. Solvents were removed again under reduced pressure to afford product.

\section{AntPOH:}

AntPet (260.5 mg, $0.8287 \mathrm{mmol})$. Bromotrimethylsilane $(317.2 \mathrm{mg}, 2.072 \mathrm{mmol})$. Precipitate formation after addition of methanol. Solvents were filtered out and precipitate was washed with cold methanol to afford pure AntPOH as a pale-yellow powder (220.7 mg, 99.54\%). ${ }^{31} \mathrm{P}\left\{{ }^{1} \mathrm{H}\right\} \mathrm{NMR}\left(162 \mathrm{MHz} ; \mathrm{CDCl}_{3}\right): \delta$ 13.81 (s). 1H NMR (700 MHz; CDCl3): $\delta$ H-13 $8.73(\mathrm{~s}, 1 \mathrm{H}), \mathbf{H}-68.61(\mathrm{~s}, 1 \mathrm{H}), \mathbf{H}-\mathbf{1} 8.47\left(\mathrm{~d}, 1 \mathrm{H},\left.\right|^{3} \mathrm{JHH}_{\mathrm{HH}} \mid=15.7\right.$ $\mathrm{Hz}), \mathbf{H}-\mathbf{4} 8.14\left(\mathrm{dd}, 1 \mathrm{H},\left.\right|^{3} \mathrm{JHH}_{\mathrm{HH}}=8.4 \mathrm{~Hz},\left.\right|^{3} \mathrm{~J}_{\mathrm{PH}} \mathrm{I}=2.8 \mathrm{~Hz}\right), \mathbf{H}-\mathbf{8}$ and $\mathbf{H}-\mathbf{1 1} 8.12(\mathrm{~m}, 2 \mathrm{H}), \mathbf{H}-\mathbf{3} 7.68(\mathrm{~m}, 1 \mathrm{H}), \mathbf{H}-\mathbf{9}$ and H-10 $7.57(\mathrm{~m}, 2 \mathrm{H}) .{ }^{13} \mathrm{C}\left\{{ }^{1} \mathrm{H}\right\}$ NMR $(175 \mathrm{MHz} ; \mathrm{CDCl} 3): \delta$ C-1 $132.15\left(\mathrm{~d},\left.\right|^{2} \mathrm{~J}_{\mathrm{CP}} \mathrm{I}=5.1 \mathrm{~Hz}\right), \mathbf{C}-7132.12(\mathrm{~s}), \mathbf{C}-$ $5131.37\left(\mathrm{~d},\left.\right|^{4} J_{\mathrm{CP}} \mid=2.5 \mathrm{~Hz}\right), \mathrm{C}-12131.56(\mathrm{~s}), \mathrm{C}-2130.98\left(\mathrm{~d},\left.\right|^{1} J_{\mathrm{CP}} \mid=180.6 \mathrm{~Hz}\right), \mathrm{C}-14129.96\left(\mathrm{~d},\left.\right|^{3} J_{\mathrm{CP}} \mid=\right.$ $16.5 \mathrm{~Hz}$ ), C-11 128.29 (s), C-13 128.10 (s), C-4 128.04 (d, | |3 J $\mathrm{CP} \mid=12.7 \mathrm{~Hz}$ ), C-8 127.57 (s), C-6 126.35 (s), C-9 $126.05(s)$, C-10 $125.93(s)$, C-3 $125.61\left(d,\left.\right|^{3} J_{C P} \mid=10.2 \mathrm{~Hz}\right)$.

\section{NapPOH:}

NapPet (1.1523 g, $4.3604 \mathrm{mmol})$. Bromotrimethylsilane (1.6689 g, $10.091 \mathrm{mmol})$. Precipitate formation after addition of methanol. Solvents were filtered out and precipitate was washed with cold methanol to 
afford pure NapPOH as a white powder (896.4 mg, 98.76\%). ${ }^{31} \mathrm{P}\left\{{ }^{1} \mathrm{H}\right\} \mathrm{NMR}\left(162 \mathrm{MHz} ; \mathrm{CDCl}_{3}\right): \delta 13.96 .{ }^{1} \mathrm{H}$ NMR $\left(700 \mathrm{MHz} ; \mathrm{CDCl}_{3}\right): \delta \mathbf{~ H - 1 1}$ (broad s, 2H), H-1 $8.30\left(\mathrm{~d}, 1 \mathrm{H},\left.\right|^{3} J_{\mathrm{HH}} \mid=15.3 \mathrm{~Hz}\right), \mathbf{H}-\mathbf{9} 8.05\left(\mathrm{~d}, 1 \mathrm{H},\left.\right|^{3} J_{\mathrm{HH}} \mid=\right.$ $8.0 \mathrm{~Hz}$ ), H-4 $7.99\left(\mathrm{dd}, 1 \mathrm{H},\left.\right|^{3} J_{\mathrm{HH}}|=8.4 \mathrm{~Hz},|^{4} J_{\mathrm{PH}} \mid=3.4 \mathrm{~Hz}\right), \mathbf{H}-67.97\left(\mathrm{~d}, 1 \mathrm{H},\left.\right|^{3} \mathrm{JHH}_{\mathrm{HH}} \mid=8.2 \mathrm{~Hz}\right), \mathbf{H}-37.73$ (ddd, $\left.1 \mathrm{H},\left|{ }^{3} J_{\mathrm{HH}}\right|=8.6 \mathrm{~Hz},\left.\right|^{3} J_{\mathrm{PH}}|=11.2 \mathrm{~Hz},|^{4} J_{\mathrm{HH}} \mid=1.5 \mathrm{~Hz}\right), \mathbf{H 7} 7.62\left(\mathrm{ddd}, 1 \mathrm{H},\left|{ }^{3} \mathrm{JHO}_{\mathrm{HH}}\right|=7.9 \mathrm{~Hz},\left.\right|^{3} \mathrm{JHO}_{\mathrm{HH}} \mid=6.8 \mathrm{~Hz}\right.$, $\left.\left|J_{\mathrm{HH}}\right|=1.3 \mathrm{~Hz}\right), \mathbf{H 8} 7.59$ (ddd, $\left.1 \mathrm{H},\left|{ }^{3} J_{\mathrm{HH}}\right|=8.0 \mathrm{~Hz},\left|{ }^{3} J_{\mathrm{HH}}\right|=6.7 \mathrm{~Hz},\left|{ }^{4} J_{\mathrm{HH}}\right|=1.1 \mathrm{~Hz}\right) .{ }^{13} \mathrm{C}\left\{{ }^{1} \mathrm{H}\right\} \mathrm{NMR}(175$ $\mathrm{MHz} ; \mathrm{CDCl}_{3}$ ): $\delta$ C-5 $133.83\left(\mathrm{~d},\left.\right|^{4} J_{\mathrm{CP}} \mid=2.5 \mathrm{~Hz}\right), \mathbf{C}-10132.02\left(\mathrm{~d},\left.\right|^{3} J_{\mathrm{CP}} \mid=8.9 \mathrm{~Hz}\right), \mathbf{C}-2131.45\left(\mathrm{~d},\left.\right|^{1} J_{\mathrm{CP}} \mid=\right.$ $172.0 \mathrm{~Hz}), \mathrm{C}-1131.32\left(\mathrm{~d},\left.\right|^{2} \mathrm{~J}_{\mathrm{CP}} \mid=12.0 \mathrm{~Hz}\right), \mathrm{C}-9128.65(\mathrm{~s}), \mathrm{C}-6$ or C-7 $127.72(\mathrm{~s}), \mathrm{C}-6$ or C-7 $127.66(\mathrm{~s}), \mathrm{C}-4$ 127.63 (obscured doublet), C-8 126.74 (s), C-3 126.63 (d, $\left.\right|^{2} J_{\mathrm{CP}} \mid=10.2 \mathrm{~Hz}$ ).

\section{DecNapPOH:}

DecNapPet (875.7 mg, $2.082 \mathrm{mmol})$. Bromotrimethylsilane (796.9 mg, $10.091 \mathrm{mmol})$. Precipitate formation after addition of methanol. Solvents were filtered out and precipitate was washed with cold methanol to afford pure DecNapPOH as a white powder $(756.7 \mathrm{mg}, 99.73 \%) .{ }^{31} \mathrm{P}\left\{{ }^{1} \mathrm{H}\right\} \mathrm{NMR}(162 \mathrm{MHz}$; $\left.\mathrm{CDCl}_{3}\right): \delta$ 14.60. ${ }^{1} \mathrm{H} \mathrm{NMR}\left(700 \mathrm{MHz} ; \mathrm{CDCl}_{3}\right): \delta \mathbf{H - 1} 8.19\left(\mathrm{~d}, 1 \mathrm{H},\left|{ }^{3} \mathrm{JPP}_{\mathrm{HP}}\right|=14.8 \mathrm{~Hz}\right), \mathbf{H}-97.94\left(\mathrm{~d}, 1 \mathrm{H},\left.\right|^{3} J_{\mathrm{HH}} \mid=\right.$ $9.0 \mathrm{~Hz}$ ), H-4 $7.84\left(\mathrm{dd}, 1 \mathrm{H},\left.\right|^{3} \mathrm{~J}_{\mathrm{HH}}|=8.4 \mathrm{~Hz},|^{4} \mathrm{~J}_{\mathrm{PH}} \mid=3.2 \mathrm{~Hz}\right.$ ), $\mathbf{H}-37.66\left(\mathrm{ddd}, 1 \mathrm{H},\left.\right|^{3} \mathrm{~J}_{\mathrm{HH}}|=8.2 \mathrm{~Hz},|^{3} \mathrm{~J}_{\mathrm{HP}} \mid=10.7\right.$ $\left.\mathrm{Hz},\left.\right|^{4} J_{\mathrm{HH}} \mid=1.3 \mathrm{~Hz}\right), \mathbf{H}-67.35\left(\mathrm{~d}, 1 \mathrm{H},\left|{ }^{4} J_{\mathrm{HH}}\right|=3.2 \mathrm{~Hz}\right), \mathbf{H}-87.21\left(\mathrm{dd}, 1 \mathrm{H},\left.\right|^{3} J_{\mathrm{HH}}|=8.8 \mathrm{~Hz},|^{4} J_{H H} \mid=3.2 \mathrm{~Hz}\right), \mathbf{H}-$ 114.13 (t, 2H), H-12 1.78 (q, 1H), H-13 1.46 (q, 1H), H-14 1.35 (q, 1H), H-15 through H-19 1.35-0.90 (m, 10H), H-20 $0.86\left(t, 1 \mathrm{H},\left.\right|^{3} J_{\mathrm{HH}} \mid=6.9 \mathrm{~Hz}\right) .{ }^{13} \mathrm{C}\left\{{ }^{1} \mathrm{H}\right\} \mathrm{NMR}\left(175 \mathrm{MHz} ; \mathrm{CDCl}_{3}\right): \delta \mathrm{C}-7157.84(\mathrm{~s}), \mathrm{C}-5135.45$ (d, $\left|{ }^{4} J_{C P}\right|=2.5 \mathrm{~Hz}$ ), C-1 $131.12\left(\mathrm{~d},\left.\right|^{2} J_{\mathrm{CP}} \mid=9.8\right), \mathbf{C}-9130.19(\mathrm{~s}), \mathbf{C}-2128.64\left(\mathrm{~d},\left.\right|^{1} J_{\mathrm{CP}} \mid=183.1 \mathrm{~Hz}\right), \mathbf{C}-10127.28$ $\left(\mathrm{d},\left.\right|^{3} J_{\mathrm{CP}} \mid=15.2 \mathrm{~Hz}\right), \mathrm{C}-3127.13\left(\mathrm{~d},\left.\right|^{2} J_{\mathrm{CP}} \mid=10.2 \mathrm{~Hz}\right), \mathbf{C}-4126.46\left(\mathrm{~d},\left.\right|^{3} J_{\mathrm{CP}} \mid=14.1 \mathrm{~Hz}\right), \mathbf{C}-8119.43(\mathrm{~s}), \mathbf{C}-6$ 106.57 (s), C-11 67.72 (s), C-12 28.62 (s), C-13 25.75 (s), C-14 through C19 31.31, 29.03, 28.97, 28.80, 28.72, $22.10(\mathrm{~s}), \mathrm{C}-2213.96(\mathrm{~s})$.

\section{General Salt Synthesis:}

A general synthesis for the phosphonate salts is as follows: Phosphonic acid (1 eq) was added to a $50 \mathrm{~mL}$ Erlenmeyer flask with $25 \mathrm{~mL}$ of freshly distilled water. Sodium hydroxide solution was added ( 2 eq of $\mathrm{NaOH}$ ) and the solution was allowed to stir. The reaction was considered complete when the solid totally dissolved in water. Water was removed by rotary evaporation under reduced pressure.

\section{AntPONa:}

AntPOH (155.6 mg, $0.4477 \mathrm{mmol})$, sodium hydroxide $(0.6536 \mathrm{~mL}, 1.370 \mathrm{M}, 0.8954 \mathrm{mmol})$. Pure AntPONa was obtained as a yellowish solid in quantitative yield (135.3 mg, 100\%).

\section{NapPONa:}

$\mathrm{NapPOH}$ (264.3 mg, $1.270 \mathrm{mmol}$ ). Sodium hydroxide (1.834 mL, $1.370 \mathrm{M}, 2.540 \mathrm{mmol}$ ). Pure NapPONa was obtained as a white solid in quantitative yield $(320.2 \mathrm{mg}, 100 \%)$.

\section{DecNapPONa:}

DecNapPOH (195.6 mg, 0.5367 mmol). Sodium hydroxide (0.7836 mL, 1.370 M, $1.073 \mathrm{mmol})$. Pure DecNapPONa was obtained as a white solid in quantitative yield $(219.2 \mathrm{mg}, 100 \%)$.

\section{Linear Optical Characterization in Solution:}


All linear absorption measurements were recorded at room temperature in $1 \mathrm{~cm}$ quartz cuvettes using a Varian Cary-100 UV/Vis spectrophotometer. Solutions of the compounds were prepared under $\mathrm{N}_{2}$ in degassed Optima grade dichloromethane or DMSO or freshly distilled water.

Fluorescence measurements were recorded at room temperature using a Varian Cary Eclipse Fluorometer. Sample concentrations were chosen to give absorption values of less than 0.10 . Each sample was excited at the $\lambda_{\max }$ band of its linear absorption. Quantum yields ( $\pm 10 \%$ ) were determined using the Equation (2):

(2) $\Phi=\Phi_{R} * \frac{I}{I_{R}} * \frac{A_{R}}{A} * \frac{n^{2}}{n_{R}^{2}}$

where $\Phi$ is quantum yield, $I$ is the integrated fluorescence intensity, $A$ is the absorbance at the excitation wavelength, and $\mathrm{n}$ is the refractive index of the sample. ${ }^{[23]}$ The subscript $\mathrm{R}$ refers to the reference sample. ${ }^{12,23}$ The reference was excited at each $\lambda_{\mathrm{ex}}$ of the samples, and the absorbance of the reference sample was recorded at each of these wavelengths.

\section{Linear Optical Characterization in Solid State:}

Quantitative 2-D and integrating sphere measurements were taking using a custom optical setup using an Oriel source lamp (66011) fitted with a Vexta Spectrograph. The incident beam was directed by a fiber optic cable and a series of mirrors to a $2 \mathrm{~cm} \times 2 \mathrm{~cm}$ glass slide evenly coated with about $75 \mathrm{mg}$ of sample. For quantum efficiency measurements, the sample was fixed in a Labsphere integrating sphere (3P-GPS-040-SF) attached with a detector. The sample was set in the open for 2D spectra with the detector set a short distance away. The detector was an Acton Research SpectraPro 300i spectrometer coupled with a Roper Scientific LN2 CCD (1340/100-EB/1) with all three slits set to $250 \mathrm{~mm}$ using integration times of $20 \mathrm{~s}$ for 2D spectra and $1 \mathrm{~min}$ for quantum efficiency measurements.

\section{X-ray Radioluminescence Characterization Methods:}

$\mathrm{X}$-ray radioluminescence spectra were collected by irradiating the sample with a mini X-ray tube equipped with a tungsten source (Amptek Inc.), operating at a tube voltage of $50 \mathrm{kV}$ and a tube current of $79 \mu \mathrm{A}$. The radioluminescence was collected with a fiber bundle (Oriel) coupled to a MicroHR (Horiba Jobin Yvon) monochromator (spectral dispersion $5.25 \mathrm{~nm} / \mathrm{mm}$ with spectral resolution of $0.25 \mathrm{~nm}$ ) and a cooled CCD detector (Synapse, Horiba Jobin Yvon). The signal was collected on a grating with 600 line/mm and a blaze of $500 \mathrm{~nm}$. The spectra were analyzed with SynerJY (Horiba Jobin Yvon) software. The exposure time was set at $10 \mathrm{~s}$ for all samples. About $20 \mathrm{mg}$ of sample were pressed into a steel washer fixed to a glass microscope slide. The x-ray tube was positioned $10 \mathrm{~cm}$ directly over the sample, and the fiber optic cable was mounted $2 \mathrm{~cm}$ below the glass slide. 
[1] K. Deisseroth, G. Feng, A. K. Majewska, G. Miesenbock, A. Ting, M. J. Schnitzer, J. Neurosci. 2006, $26,10380-10386$.

[2] Science (80-. ). 2010, 330, 1612-1613.

[3] E. Pastrana, Nat. Methods 2011, 8, 24-25.

[4] D. Huber, L. Petreanu, N. Ghitani, S. Ranade, T. Hromádka, Z. Mainen, K. Svoboda, Nature 2008, 451, 61-64.

[5] A. R. Adamantidis, F. Zhang, A. M. Aravanis, K. Deisseroth, L. de Lecea, Nature 2007, 450, 420424.

[6] A. M. Aravanis, L.-P. Wang, F. Zhang, L. A. Meltzer, M. Z. Mogri, M. B. Schneider, K. Deisseroth, J. Neural Eng. 2007, 4, S143-S156.

[7] T. -i. Kim, J. G. McCall, Y. H. Jung, X. Huang, E. R. Siuda, Y. Li, J. Song, Y. M. Song, H. A. Pao, R.-H. Kim, et al., Science (80-. ). 2013, 340, 211-216.

[8] M. A. Long, M. S. Fee, Nature 2008, 456, 189-194.

[9] J. L. Sandell, T. C. Zhu, J. Biophotonics 2011, 4, 773-787.

[10] A. M. Brouwer, Pure Appl. Chem. 2011, 83, 2213-2228.

[11] S. M. Schieke, P. Schroeder, J. Krutmann, Photodermatol. Photoimmunol. Photomed. 2003, 19, 228-234.

[12] T. L. Moore, F. Wang, H. Chen, S. W. Grimes, J. N. Anker, F. Alexis, Adv. Funct. Mater. 2014, 24, 5815-5823.

[13] H. Chen, D. E. Longfield, V. S. Varahagiri, K. T. Nguyen, A. L. Patrick, H. Qian, D. G. VanDerveer, J. N. Anker, Analyst 2011, 136, 3438.

[14] S. Chen, A. Z. Weitemier, X. Zeng, L. He, X. Wang, Y. Tao, A. J. Y. Huang, Y. Hashimotodani, M. Kano, H. Iwasaki, et al., Science (80-. ). 2018, 359, 679-684.

[15] P. Coan, A. Bravin, G. Tromba, J. Phys. D. Appl. Phys. 2013, 46, 494007.

[16] D. N. French, A. F. Bartley, K. Abiraman, M. Bagley, B. Grant, T. M. McFarlane, O. Klep, C. Kucera, M. K. Burdette, L. E. Dobrunz, L. McMahon, S. H. Foulger, G. M. Gray. ChemRxiv. 2020. https://doi.org/10.26434/chemrxiv.12709598.v1.

[17] M. Yeh, S. Hans, W. Beriguete, R. Rosero, L. Hu, R. L. Hahn, M. V. Diwan, D. E. Jaffe, S. H. Kettell, L. Littenberg, Nucl. Instruments Methods Phys. Res. Sect. A Accel. Spectrometers, Detect. Assoc. Equip. 2011, 660, 51-56.

[18] K. Kosswig, in Ullmann's Encycl. Ind. Chem., Wiley-VCH Verlag GmbH \& Co. KGaA, Weinheim, Germany, 2000.

[19] P. Goon, C. Manohar, V. V. Kumar, J. Colloid Interface Sci. 1997, 189, 177-180.

[20] S. Satpathi, K. Gavvala, P. Hazra, Phys. Chem. Chem. Phys. 2015, 17, 20725-20732. 
[21] M. K. Burdette, Y. P. Bandera, E. Zhang, A. Trofimov, A. Dickey, I. Foulger, J. W. Kolis, K. E. Cannon, A. F. Bartley, L. E. Dobrunz, et al., Langmuir 2019, 35, 171-182.

[22] Glenn F. Knoll, Radiation Dectection Measurement, John Wiley \& Sons, 2000.

[23] D. N. French, J. G. Simmons, H. O. Everitt, S. H. Foulger, G. M. Gray. In Preparation - European Journal of Inorganic Chemistry.

[24] Q. Zhao, J. Wang, J. L. Freeman, M. Murphy-Jolly, A. M. Wright, D. J. Scardino, N. I. Hammer, C. M. Lawson, G. M. Gray, Inorg. Chem. 2011, 50, 2015-2027.

[25] J.-M. Rueff, O. Perez, A. Pautrat, N. Barrier, G. B. Hix, S. Hernot, H. Couthon-Gourvès, P.-A. Jaffrès, Inorg. Chem. 2012, 51, 10251-10261.

[26] E. A. Dennis, A. Plückthun, in Phosphorous-31 NMR, Elsevier, 1984, pp. 423-446.

[27] C. Chachaty, Prog. Nucl. Magn. Reson. Spectrosc. 1987, 19, 183-222.

[28] I. A. Khan, R. Mohammad, M. S. Alam, Kabir-ud-Din, J. Dispers. Sci. Technol. 2009, 30, 14861493.

[29] L.-J. Chen, S.-Y. Lin, C.-C. Huang, J. Phys. Chem. B 1998, 102, 4350-4356.

[30] S. Kao, A. N. Asanov, P. B. Oldham, Instrum. Sci. Technol. 1998, 26, 375-387.

[31] in Mol. Fluoresc., Wiley-VCH Verlag GmbH \& Co. KGaA, Weinheim, Germany, 2012, pp. 213-261.

[32] S. Shimizu, P. A. R. Pires, O. A. El Seoud, Langmuir 2003, 19, 9645-9652.

[33] T. Hinoue, Y. Shigenoi, M. Sugino, Y. Mizobe, I. Hisaki, M. Miyata, N. Tohnai, Chem. - A Eur. J. 2012, 18, 4634-4643.

[34] J. C. de Mello, H. F. Wittmann, R. H. Friend, Adv. Mater. 1997, 9, 230-232.

[35] J. V. Foreman, J. G. Simmons, W. E. Baughman, J. Liu, H. O. Everitt, J. Appl. Phys. 2013, 113, 133513.

[36] J. G. Simmons, J. V. Foreman, J. Liu, H. O. Everitt, Appl. Phys. Lett. 2013, 103, 201110.

[37] W. R. Leo, Techniques for Nuclear and Particle Physics Experiments, Springer Berlin Heidelberg, Berlin, Heidelberg, 1994.

[38] H. Oikawa, T. Mitsui, T. Onodera, H. Kasai, H. Nakanishi, T. Sekiguchi, Jpn. J. Appl. Phys. 2003, 42, L111-L113.

[39] P. Schuster, P. Feng, E. Brubaker, IEEE Trans. Nucl. Sci. 2018, 65, 1292-1306.

[40] J. Ferguson, A. W. H. Mau, Mol. Phys. 1974, 28, 469-477. 